Revista de Estudios Histórico-Jurídicos

[Sección historia del derecho europeo]

XLII (Valparaíso, Chile, 2020)

[pp. 319-346]

\title{
Direito, Construção e Ambiente: o Quadro \\ NORMATIVO PORTUGUÊS PARA A CONSTRUÇÃO DE FORNOS de pão na transição da IdAde Média Para A Moderna*
}

[Law, construction and environment: the Portuguese regulatory framework to build bread ovens in the transition from the Middle Ages to Modern Times]

\author{
Sandra M.G. PINTO** \\ Universidade Nova de Lisboa, Portugal
}

\section{RESUMEN}

Este artículo trata de las normas jurídicas establecidas por las autoridades portuguesas para regular la construcción de hornos, en particular los hornos de pan. Su objetivo era impedir que estas estructuras causasen daños a la vecindad. El análisis de estas normas jurídicas permite presenciar un cambio socio-ambiental ocurrido en Portugal durante la transición de la Edad Media a la Edad Moderna: la polución del aire pasó a formar parte de los problemas de salubridad pública.

\section{Palabras Clave}

Regulación de la construcción - hornos de pan - costumbres locales - polución del aire - Portugal; Edad Media y Moderna.

\section{AbStRaCt}

This article is about the legal norms set forth by the Portuguese authorities to regulate the construction of ovens, particularly, bread ovens. These norms were aimed at preventing their structure causing harm to the neighborhood. The analysis of the aforementioned norms allows us to witness a socio-environmental change that took place during the transition from the Middle Ages to Modern Times in Portugal: the air pollution became part of the public health agenda.

\section{KeY WORDS}

Construction regulations - bread ovens - local customs - air pollution - Portugal; Middle Ages and Modern Times.

ReCibido el 23 de marzo de 2019 y ACEPTADO el 13 de enero de 2020

\section{INTRODUÇÃO}

Não são muitos os dados que permitem perceber como foi regulada a construção de fornos em Portugal para períodos anteriores à contemporaneidade ${ }^{1}$,

\footnotetext{
* Este trabalho é financiado por fundos nacionais através da FCT - Fundação para a Ciência e a Tecnologia, I.P., no âmbito da Norma Transitória - DL 57/2016/CP1453/CT0026.

** Doutorada contratada pela Faculdade de Ciências Sociais e Humanas, da Universidade NOVA de Lisboa e investigadora integrada no CHAM - Centro de Humanidades. Direção postal: Avenida de Berna, 26-C, 1969-061, Lisboa, Portugal. Correio eletrónico: sandramgpinto@ gmail.com. ORCID 0000-0002-7367-3148.
} 
algo que, naturalmente, justifica a ausência de estudos dedicados ao tema ${ }^{2}$. Esta condição não é, aliás, nem uma novidade, nem uma exceção nos estudos históricos que tratam do ordenamento jurídico para a construção, verificando-se a mesma ausência informativa para muitas outras estruturas construídas, quer habitacionais, quer utilitárias.

Todavia, os fornos foram estruturas indispensáveis para várias atividades produtivas ou transformadoras dependentes do processo de cozedura e, por isso mesmo, existiram em quase todas, senão mesmo em todas, povoações. Alguns investigadores consideram-nos até, como o "Élément primordial de la vie quotidienne" ${ }^{\text {. A }}$ sua importância é ainda verificada pelos inúmeros registos toponímicos referentes a fornos, ou a variantes como fornalha ou fornalhinha .

Os fornos podiam ser de muitos tipos: os de telhas, os de olaria, os de cal, os de vidro, os de ferraria (fráguas), os dos banhos, e também os de pão. Todos eles eram responsáveis por potenciais danos de vizinhança, não só devido ao risco de incêndio, mas ainda por causa do fumo emitido pela queima do material combustível, criando, eventualmente, inconvenientes e receios nos vizinhos ou até conflitos socio-ambientais.

Mas se os fornos que coziam peças cerâmicas ou que transformavam os materiais poderiam ser arredados para áreas limítrofes dos espaços urbanos 5 , já os fornos

${ }^{1} \mathrm{Na}$ sequência das reformas liberais, do século XIX, as atividades produtivas passaram a ser reguladas e licenciadas com maior rigor, de modo a garantir a segurança e salubridade das povoaçōes [PINTO, Sandra M.G., O licenciamento dos estabelecimentos insalubres, incómodos ou perigosos no século XIX e as plantas dos processos do distrito de Coimbra, in Boletim do Arquivo da Universidade de Coimbra, 31/1 (2018), pp. 125-162].

${ }^{2}$ Para além da síntese produzida por Barros, Henrique Gama, História da administração pública em Portugal nos séculos XII a XV (Lisboa, 1885-1922), IV, pp. 115-119, seguida de perto por MARQUES, A.H. de Oliveira, Introdução à história da agricultura em Portugal. A questão cerealifera durante a Idade Média (Lisboa, 1978), pp. 201-202, encontram-se apenas estudos que abordam a propriedade e gestão dos fornos, como o de MARQuEs, José, D. Manuel I e os fornos comunitários transmontanos, in Amar, sentir e viver a história: Estudos de homenagem a Joaquim Veríssimo Serrão (Lisboa, 1995), pp. 647-659, e DuTRA, Francis A., Os fornos da Ordem de Santiago e seus Comendadores 1550-1777, in Ordens Militares. Guerra, religião, poder e cultura: Actas do III Encontro sobre Ordens Militares (Lisboa, 1999), pp. 179-183.

${ }^{3}$ Higounet-Nadal, Arlette, Périguex aux XIVe et XVe siècles. Étude de démographie historique (Université de Lille III, 1979), I, p. 80.

${ }^{4}$ Entre outros exemplos possíveis, veja-se os topónimos de Évora [CARVAlHo, Afonso, $D a$ toponimia de Évora (Lisboa, 2004-2007), I, pp. 181-183; II, pp. 105-106].

${ }^{5}$ Em rigor, não se encontraram disposições jurídicas medievais que claramente determinassem a localização ou o afastamento urbano das atividades fumegantes. Tal encontra-se, sim, para as atividades barulhentas e mal cheirosas. Por exemplo, em Lisboa, estabeleceu-se que " $n a m$ seJa nenhũu tam ousado que daquy em dyamte faça de nouo nem adube tones nem pipas na rrua noua nem loJeas della nem Outrossy talhe ferro na dicta rrua noua nem loJeas nem nas dictas loJeas tenha salga de pescado nem de coyros nem salgue sardinha pera carregar nem rrevender", e que "nam seJa nenhũ tam ousado que lançe coyros verdes nem sequos a enxugar nem a sequar em nenhũa parte da çidade dos muros adentro e aquelles que os enxugar quiserem que o façam arredor da çidade fora dos muros" [Livro das Posturas Antigas (Lisboa, 1974), pp. 60, 142]. Não obstante, não é raro encontrarem-se unidades produtivas com fornos fora das cercas urbanas, como se depara em Évora, quando a vereação, em 1492, afora um chão do lado de fora do muro, "antre o poço dalconchel e o muro e a porta dalconchel [...] pera fazer nele hũua casa e hũu forno e hũu telhal 
de pão não. Com efeito, estes não podiam ficar muito afastados das habitações devido à necessidade diária e permanente daquele que era um dos mais básicos e imprescindíveis alimentos da dieta medieval e moderna ${ }^{6}$. Ora, além dos fornos caseiros, onde cada família cozia o próprio pão, existiram ainda fornos de maiores dimensōes, coletivos ou comunitários, com utilização pública, muitas vezes a cargo das forneiras. Estes últimos eram chamados fornos de poia, sendo a poia a forma de pagamento pela utilização do forno, normalmente liquidado através de uma das unidades cozidas em cada fornada ${ }^{7}$.

Não é, pois, por acaso que de todos os tipos de fornos referidos seja para os de pão que se encontram as mais antigas normas jurídicas para regular a sua construção. Saliente-se que estas normas não tratam dos materiais, do formato ou das técnicas construtivas. Abordam, sim, as condições específicas para que a sua presença provocasse o menor prejuízo possível no ambiente urbano envolvente. Mais, tais normas só foram definidas quando havia liberdade de construção dessas estruturas, algo que, como se verá a seguir, também dependia de disposições jurídicas.

Neste artigo propõe-se, então, elencar as normas jurídicas que se encontraram na documentação tardo-medieval e do início do período moderno para regular a construção de fornos de pão, fazendo-lhes ainda uma breve análise crítica de modo a contribuir com um pequeno subsídio para história do direito português relacionado com a construção.

\section{DA LIBERdAde DE CONSTRUÇÃO}

De acordo com Henrique Gama Barros, a liberdade de qualquer pessoa poder construir fornos de pão variava caso a povoação pertencesse à coroa ou a outro senhorio $^{8}$, tal como se depreende nos primeiros documentos normativos das povoaçôes portuguesas, seja nos forais ou cartas de foro, seja nos foros ou costumes?.

e emxugadoyro" porque lhes "aprazia dello darem pera fazer o dicto forno e casa dolaria e telhal" [Arquivo Nacional Torre do Tombo = ANTT, Leitura Nova, Odiana Livro 1, fl. 294v-295v].

${ }^{6}$ Entre outros estudos que abordam as práticas alimentares, ver GONÇALVES, Iria, A propósito do pão da cidade na Baixa Idade Média, in Turres Veteras IX. História da Alimentação (Torres Vedras, 2007), pp. 49-72.

${ }^{7}$ Por exemplo, durante o medievo, a poia correspondia a um pão por cada 20 em Évora e a um pão por cada $30 \mathrm{em}$ Arraiolos [Os regimentos de Évora e de Arraiolos (Évora, 2012), pp. 59, 111]. Em Lisboa, no século XV, a poia era um pão por cada 12, caso fosse igual aos outros, ou metade do valor em dinheiro se na fornada tivesse apenas 6 , passando, no século XVI, a ser um pão por cada 15 [Livro das Posturas, cit. (n. 5), pp. 92 e 253].

${ }^{8}$ Barros, Henrique Gama, cit. (n. 2), IV p. 115. Como paralelo no reino de Aragão, ver Piedrafita Pérez, Elena, Infraestructura económica de los concejos de las Cinco Villas: regadios, molinos y hornos (siglos XII-XIV), in Aragón en la Edad Media, 12 (1995), pp. 29-60.

${ }^{9}$ Os primeiros regulavam as relações jurídicas entre os habitantes e a entidade outorgante; os últimos regulavam as relaçóes jurídicas entre os habitantes e vizinhos dos concelhos com eles próprios ou com os poderes concelhios. Ver a síntese de Alexandre Herculano, em Portugaliae Monumenta Historica, a saeculo octavo post christum ad quintumdecimum, Leges et Consuetudines $I$ (Lisboa, 1856), pp. 740-742, bem como, as obras gerais de história do direito português: CaEtano, Marcello, História do direito português: Fontes - Direito público (1140-1495) (Lisboa, 
Efetivamente, as mais antigas disposições sobre fornos encontram-se nos forais outorgados pelos primeiros monarcas portugueses. No foral de Évora de 1166 aparece: "Tendas et molinos et fornos de homines de Elbora sint liberi de foro", e no foral de Coimbra de 1179, como também nos de Santarém e de Lisboa do mesmo ano, surge: "Et habitatores de Colimbrie habeant libere tendas, fornos, panis scilicet et ollarum"10. Daqui, retira-se que os fornos de pão (e também outros fornos com exceção dos de telhas que pagavam dízimo-, além das tendas, moinhos ou lagares) não pagavam impostos, deduzindo-se pela isenção fiscal que qualquer pessoa os podia construir.

Como os forais referidos serviram de modelo para muitas outras cartas de foro, encontram-se idênticas cláusulas nos forais de cerca de meia centena de povoaçôes ${ }^{11}$. Acresce ainda a esta lista Melgaço, dado que o seu foral de 1185, baseado no Ribadávia, que por sua vez seguia o Sahagún, excluía igualmente dos impostos os fornos (e ainda moinhos e almuinhas), determinando: "et de uestris molendinis ac fornacibus, et de uestra almunia nulli respondeatis nisi soli deo" 12 .

São, contudo, os costumes da região de Riba-Côa, nomeadamente de Alfaiates, datado de entre 1209 e 1229, de Castelo Rodrigo, datado de entre 1211 e 1237, de Castelo Bom e Castelo Melhor, ambos posteriores a $1237^{13}$, que manifestam claramente a liberdade de construção de fornos, neles se lendo que qualquer um

1985 [1. ${ }^{a}$ ed. 1981]), pp. 231-239, 352-354; Hespanha, António Manuel, História das instituições, Épocas medieval e moderna (Coimbra, 1982), pp. 175-181; SILVA, Nuno Espinosa Gomes, História do direito português, Fontes de direito (Lisboa, 2011 [1. a ed. 1985]), pp. 169176; Costa, Mário Júlio Almeida, História do direito português (Coimbra, 2009 [1. a ed. 1989]), pp. 205-209; Albuquerque, Ruy de; Albuquerque, Martim de, História do direito português, 1140-1415 (Sintra, 2005 [1. a ed. 1992]), pp. 227-238; HespanHa, António Manuel, Cultura jurídica europeia, sintese de um milénio (Coimbra, 2012 [1. ${ }^{\mathrm{a}} \mathrm{ed}$. 1997]), pp. 181-182.

${ }^{10}$ Portugaliae, cit. (n. 9), pp. 392, 406-407, 412, 416.

${ }^{11}$ Sobre as famílias foralengas, ver REIs, António Matos, Origem dos Municípios Portugueses (Lisboa, 2002). Baseados no foral de Évora, e com indicação precisa à norma sobre os fornos, encontram-se os forais de: Abrantes (1179), Coruche (1182), Palmela (1185), Covilhã (1186), Centocelas (1194), São Vicente da Beira (1195), Benavente (1200), Sesimbra (1201), Alpedrinha (1202), Montemor-o-Novo (1203), Teixeiras e Souto de Rodrigo (1206), Penamacor (1209), Pinhel (1209), Sarzedas (1212), Castelo Branco (1213), Alcácer (1218), Manteigas (1220), Proença-a-Nova (1222 e 1244), Avis (1223), Marvão (1226), Sortelha (1228-1228), Idanhaa-Velha (1229), Salvaterra (1229), Elvas (1229), Alter do Chão (1232), Crato (1232), Canha (1235), Aljustrel (1252), Mértola (1254), Arronches (1255), Alcáçovas (1258), Portel (1262) e Seda (1261) [Portugaliae, cit. (n. 9), pp. 419, 427, 430, 457, 487, 495, 513, 516, 521, 525, 533, 539, 542, 556, 567, 580, 585, 590, 595, 606, 608, 613, 617, 619, 623, 625, 626, 631, 637, 641, 651, 690, 704, 720]. Baseados no foral de Coimbra-Santarém-Lisboa, a especificação sobre os fornos também se encontra nos forais de: Almada (1190), Povos (1195), Leiria (1195), Alcobaça (1210), Montemor-o-Velho (1212) Alenquer (1212), Vila Franca de Xira (1212), Torres Vedras (1250), Beja (1254), Odemira (1255), Monforte (1257), Estremoz (1258), Vila Viçosa (1270) e Evoramonte (1271) [Portugaliae, cit. (n. 9), pp. 475, 491, 496, 548, 557, 559, 563, 634, 641, 664, 670, 680, 717, 722].

${ }^{12}$ ReIs, António Matos, cit. (n. 11), pp. 86-88; Portugaliae, cit. (n. 9), p. 422.

${ }^{13}$ Utilizam-se as datas dos costumes indicadas em Domingues, José; PinTo, Pedro, Os foros extensos na Idade Média em Portugal, in REHJ., 37 (2015), pp. 155-160. Ver também NogUEIRA, José Duarte, A organização municipal da Extremadura Leonesa nos sécs. XII e XIII, in Boletim da Faculdade de Direito, 58/2 (1982), pp. 374-388, 404-408, 412-421. 
os podia fazer: "et fatiat forno qui facere uoluerit"; "E faça forno qui fazer queser"; "et faciat forno qui uoluerit"; "e faga forno qui fazer quisier"14.

Pelo contrário, no foral outorgado pela Ordem de Santiago a Setúbal, em 1249, a entidade religiosa-militar reservou para si, entre outras estruturas, os fornos: "Et nos debemus habere omnes furnos et alfandegas et tendas et aljazarias et balnea in Setuual'. Já o Mosteiro de São Vicente de Fora de Lisboa, na sua carta de foro aos povoadores de São Julião do Tojal de 1258, proibiu expressamente os moradores de construírem fornos (como também lagares): "Nulli autem illorum in nostro termino furnum facere aut torcular in aliquo tempore indulgemus" 15 .

O Mosteiro de Alcobaça também monopolizou uma série de instrumentos de transformação, competindo-lhe construí-los, conservá-los, e pô-los a funcionar em todas as suas terras, sujeitando, assim, as populações à sua utilização coerciva ${ }^{16}$. Nas suas cartas de povoamento, e não obstante quase sempre terem como modelo o foral régio de Santarém, surge a reserva dos fornos para o próprio senhorio, tal como se percebe nas que foram dadas a Barrantes em 1321 ("E retéémos pera nos per nosso senhorio, alcadarya, móórdomado, portagees, açougues, fornos, moynhos, acenhas, rrelego e todolos outros senhorios reeaes") ${ }^{17}$, ou a Alfeizeirão em 1422 ("Mais reservamos pera nos moinhos e acenhas feitas e por fazer, pisões, lagares de vinho e d'azeite, fornos, relegos, açougagens, portagens, mordomado, alcaidera e todos outros senhorios e direitos reais per qualquer guisa que sejam, tambem do mar e do rio como da terra") ${ }^{18}$.

Por seu lado, a Ordem de Cristo no intuito de deter a jurisdição do forno da vila de Meda, pertencente à sua comenda, escambou com o concelho, no início do século XVI, metade dos direitos da portagem, do mordomado e da alcaidaria, "pollo forno que agora hi tem a hordem. d onde ficou que nenhũu morador do dicto logo nom pode hi teer forno. se nam a hordem" ${ }^{19}$. Daí que na documentação das ordens militares seja frequente encontrar expressōes que confirmavam expressamente este monopólio: "os fornos sam da Ordem e nom pode pesoa alguma fazer forno na dita villa senam a Ordem" 20.

${ }^{14}$ Portugaliae, cit. (n. 9), pp. 808, 881, 763, 925-926. Idênticas normas encontram-se noutras povoaçôes pertencentes, hoje, à Espanha (caso de Cáceres, Usagre, Coria), pois derivaram do mesmo direito costumeiro que foi outorgado naquele antigo território de Leão, até o lado ocidental ter sido separado e incorporado no território de Portugal com o Tratado de Alcanices de 1297 [TAvares, Maria Alice, Costumes e foros de Riba-Côa: Normativa e sociedade (Doutoramento, Universidade de Lisboa, 2013), p. 222].

${ }^{15}$ Portugaliae, cit. (n. 9), pp. 634, 684. Sobre os abusos da Ordem de Santiago relativamente aos fornos de Setúbal, ver Marques, José, A Ordem de Santiago e o concelho de Setúbal, em 1341, in As Ordens Militares em Portugal e no Sul da Europa (Lisboa, 1992), pp. 296-297, 303.

${ }^{16}$ Gonçalves, Iria, O património do Mosteiro de Alcobaça nos séculos XIV e XV (Lisboa, 1989), pp. 125-126, 457-459.

${ }^{17}$ Doc. 17 publicado por De Carvalho, Maria José Pereira, Documentação Medieval do Mosteiro de Santa Maria de Alcobaça (sécs. XIII-XVI). Edição e estudo linguístico (Doutoramento, Universidade de Coimbra, 2006), pp. 51-53.

${ }^{18}$ Carta de foro publicada por BARros, Henrique Gama, cit. (n. 2), III, pp. 592-593.

${ }^{19}$ Tombos da Ordem de Cristo (Lisboa, 2002-2014), VII, p. 139.

${ }^{20}$ Pimenta, Maria Cristina, As Ordens de Avis e de Santiago na Baixa Idade Média: O governo de D. Jorge (Porto, 2001), p. 151. 
Ora, a completa jurisdição sobre os fornos de pão por parte das instituições religiosas e religiosas-militares parece ter sido, senão a regra, pelo menos um desígnio, criando-se conflitos com outras entidades que os construíam. A título de exemplo cite-se o litígio, ocorrido em 1410, entre o concelho de Albufeira e a Ordem de Avis. Os últimos mandaram derrubar os fornos e as fornalhas de cozer pão edificados pelos moradores da terra, pois alegavam que "non deviam os dictos moradores da dicta villa nem outros nenhuns do termo de teer nenhuns fornos nem fornalhas salvo os fornos da dicta sua ordem que pertençiom a el dicto senhor Mestre", tendo na sentença sido acordada exatamente esta proibição ${ }^{21}$. Também o Mosteiro de Alcobaça, em 1437, mandou demolir os fornos e fornalhas que os moradores de Maiorga tinham feito em suas casas ${ }^{22}$.

Não se consegue precisar se as prerrogativas ou proibições instituídas pelos senhorios eclesiásticos tiveram algum papel na alteração jurídica que se verifica sobre esta matéria nos forais régios outorgados por $\mathrm{D}$. Afonso III às povoações do Algarve, no extremo sul do reino ${ }^{23}$. Mas, de facto, embora se baseassem no foral de Lisboa de 1179, os forais de Silves de 1266 e seus derivados, caso de Castro Marim de 1277, de Loulé, de Faro e de Tavira possivelmente do mesmo ano, passaram a reservar para o rei e seus sucessores o direito sobre todos os fornos de pão (e também salinas) já construídos ou a construir: "et retineo mihi et omnibus

${ }^{21}$ Excetuaram-se apenas os lavradores com duas juntas de bois no reguengo da Ordem localizado no termo da vila. Doc. 4 publicado por Cunha, Maria Cristina; Pimenta, Maria Cristina, A comenda de Albufeira da Ordem de Avis nos inícios do século XV: breve abordagem, in Actas das I Jornadas do Algarve e da Andaluzia (Loulé, 1987), pp. 341-345.

${ }^{22}$ Marques, A.H. de Oliveira, cit. (n. 2), p. 202; GonÇAlves, Iria, cit. (n. 16), pp. 126, 457-458.

${ }^{23}$ Para Mattoso, José, A consolidação da monarquia e a unidade política, in História de Portugal (Lisboa, 1993), II, p. 271, tal ação derivou de uma política concertada de D. Afonso III, já que "o interesse deste pela moeda e por bens urbanos muda qualitativamente, porque se desdobra por todo o género de instrumentos de produção, sob a forma de monopólios de fornos, moinhos, tendas, salinas, pesca da baleia, banhos, pisões, açougues ou azenhas, e inclui ferrarias, taracenas, estaleiros de construção naval". Porém, não parece descabido pensar-se que tal influência também possa ter advindo das leis criadas pelo seu sogro, Alfonso X de Castela, para a recém-conquistada cidade de Sevilha. Com efeito, se nas Ordenanzas de Sevilla (c. 1248), aparece uma proibição para construção de fornos: "Et ninguno non puede fazer forno en su casa, si non fuere por mandado del rey" [doc. I, título 24 "Huso e custumbre de los que quieren fazer fornos e molinos e lagares dazeite a de uino", publicado por GONZÁLEZ ARCE, José Damián, Cuadernos de ordenanzas y otros documentos sevillanos del reinado de Alfonso $X$, in Historia, Instituciones, Documentos, 16 (1989), p. 114]; no Libro del Peso de los Alarifes y Balanza de Menestrales, da mesma cidade e produzido pouco tempo depois, passou a estar claramente definida a posse régia de todos os fornos, ainda que o rei pudesse doá-los, por mercê, a outras pessoas: "Outrosi dezimos que todos los hornos por do quier que seã deuen ser del rey sino los que el diere a algun onme; o los que el rey mandare fazer a alguno por le fazer merced; e todo ome que fiziere horno; quier sea el suelo suyo o quier del rey; deue lo fazer de guisa que no haga daño a sus vezinhos" [Capitulo. xix. de los hornos, Ordenanças de Seuilla, Recopilacion de las ordenanças de la muy noble [et]muy leal cibdad de Seuilla de todas las leyes [et] ordenamientos antiguos [et] modernos cartas [et] p[ro] uisiones reales (Sevilla, 1527), fl. CXLIIII]. 
sucessoribus meis in perpetuum omnes furnos panis et omnes salinas constructos et construendos constructas et construendas" 24 .

Diferentemente, na região nordeste do reino, Trás-os-Montes, o rei acabou por entregar o direito sobre os fornos às entidades concelhias. Com efeito, quando D. Dinis, em 1289, concede a carta de foro a Vila Real de Panóias, para o estabelecimento de uma povoação de cerca de mil famílias, outorga a construção e exploração dos fornos (e moinhos) ao próprio concelho: "E que o Conçelho aia pera sy os Moynhos e os fornos" 25 . Também o concelho de Mós de Moncorvo detinha a posse dos fornos, ainda que depois os arrendasse a terceiros, mantendo-se, contudo, responsável pela sua construção e reparação, tal como se afere nas obras ocorridas em $1439^{26}$. Situação idêntica encontra-se no concelho de Vilas Boas, que detinha a jurisdição dos fornos de cozer o pão, pagando, porém, a terça ao rei ${ }^{27}$.

Semelhante reserva régia, relativamente à jurisdição dos fornos de pão e sua doação a uma outra entidade, depara-se nas povoações das ilhas descobertas no oceano Atlântico. São várias as cartas de doação de capitanias onde se depreende a interdição da livre construção destas estruturas, pois passavam a fazer parte do monopólio dos capitães-donatários. De ressaltar contudo, que este monopólio não foi tão exigente como acontecia nos senhorios eclesiásticos, já que a mesma disposição régia acrescentava que não se podia impedir a construção de fornalhas por quem apenas quisesse cozer o seu próprio pão. $\mathrm{O}$ articulado, quase sempre igual, dispunha, o seguinte: "que todollos fornos de pam em que ouuer poya seiam seus. E porem nom embargue quem quiser fazer fornalha pera sseu pam que a faça $e$ nom pera outro nehuu". Assim se descobre nas doações pelo infante D. Henrique da capitania de parte da ilha da Madeira (entre além do rio do Caniço até à ponta do Tristão) ao cavaleiro Tristão em 1440; da ilha de Porto Santo a Bartolomeu Perestelo em 1446; e da capitania de parte da ilha da Madeira (entre além do rio do Caniço através da serra até à ponta do Tristão) a João Gonçalves Zargo em 1450. A disposição só mudou ligeiramente na doação da capitania do Funchal ao cavaleiro Henrique alemão em 1457, aparecendo: "que em a dita terra e lugar nom faça fornos nem moinhos nem emgenhos dagoa salluo fornalhas e moo de braço em que cozam e moyam pera suas casas e mais nom" 28 .

O primeiro articulado referido foi mais tarde utilizado: pelo duque de Viseu, D. Diogo, nos Açores na doação da capitania da Praia da ilha Terceira a Álvares Martins em 1474, na doação da capitania da ilha de São Miguel a Rui Gonçalves da Câmara em 1474, e, na doação da capitania da parte de Angra da ilha Terceira e da capitania da ilha de São Jorge ambas a João Vaz Corte Real em 1474 e 1483; por D. Manuel (enquanto duque de Beja) na doação da capitania da metade setentrional da ilha de Santiago de Cabo Verde a Rodrigo Afonso em 1485; e por

${ }^{24}$ Portugaliae, cit. (n. 9), pp. 706, 734, 736, 737.

${ }^{25}$ ANTT, Chancelaria de D. Dinis, Livro 1, fl. 247v-248v.

${ }^{26}$ Marques, José, A administração municipal de Mós de Moncorvo em 1439, in Brigantia, Revista de Cultura, 5-2/3/4 (1985), pp. 523, 531, 543-544.

${ }^{27}$ Sentença de 11 de fevereiro de 1512, publicada por MARQUES, José, cit. (n. 2), pp. 657-659.

${ }^{28}$ Docs. 318, 353, 385, 423, em Descobrimentos Portugueses, Documentos para a sua História, Vol. I (1147-1460) (Lisboa, 1944), pp. 403-405, 449-450, 483-485, 541-542. 
D. João II na doação da capitania da ilha de São Tomé a João Pereira em 1490 e a Álvaro Caminha em 1493, novamente dada por D. Manuel I (já como rei), a Fernão de Melo em $1499^{29}$. Por certo, a faculdade de os moradores poderem construir fornalhas para cozer o próprio pão, e assim se libertarem do pagamento da poia, teria, presumivelmente, uma forte adesão comunitária ${ }^{30}$, justificando o seu pedido e, consequentemente, a sua anuência, mesmo em terras senhoriais. Nesse sentido, quando, em 1455, o concelho de Faro se queixa a D. Afonso $\mathrm{V}$ do mau estado físico dos seus fornos, solicita que, enquanto tal situação se mantivesse, "podesse cada morador ter uma fornalha onde cozesse o seu pão, e não outro" 31 . Também a vereação do concelho de Vilas Boas estabeleceu "que quallquer morador do dito comcelho podesse livrememte fazer fornalha em sua casa pera cozer seu pam e nom fosse obrigado a cozer ao forno do dito comcelho e nom pagasse poya alguua do pam que na dita fornalha cozesse", ainda que, por sentença de 1512, se tenha voltado à situação anterior, mandando o oficial régio derrubar os fornos e fornalhas particulares entretanto construídos ${ }^{32}$.

Da mesma forma, o Mosteiro de Alcobaça, em 1467, no seguimento de uma contenda que envolvia os rendeiros do forno velho e do forno novo de Maiorga (e cujo desfecho levou o concelho a comprar os dois fornos ao Mosteiro), passou a permitir a qualquer pessoa "fazer fornos he fornalhas em suas casas he honde lhes aprouer asy de poias como pera seu pam e nõm darem ne[m] paguarem delles ne[n] huu $[\mathrm{m}]$ derreyto a elle, dito senhor, ne [m] a seu mosteyro", pagando somente uma taxa anual como poia ${ }^{33}$. Já a Ordem de Cristo, no início do século XVI, admitiu idêntica construção particular em algumas vilas, acrescentando, contudo, que só sogras e noras podiam usar as fornalhas umas das outras, como se depara em Soure, onde "nenhuua pessoa da dita villa nom pode teer forno de poya. saluo a hordem. E quem quiser em sua casa fazer fornalha pera cozer seu pam. pode a fazer. e nom pode nella cozer outra alguua pessoa se nom for sogra com nora"; ou em Pombal, onde "os fornos de cozer pam som da hordem. e nenhuua pessoa do conçelho nom pode fazer forno que coza per poya se nom a hordem, e se alguém cozer por poya. derribem lhe o

${ }^{29}$ Docs. 105, 108, 110, 172, 188, 241, 272, em Descobrimentos Portugueses, Documentos para a sua História, Vol. III (1461-1500) (Lisboa, 1971), pp. 138-140, 143-145, 147-149, 259-260, 281-283, 359-360, 404-405.

${ }^{30}$ Para contraponto, note-se que na cidade Real de las Palmas na ilha da Grande Canária, do reino vizinho, não existiam fornos de poia públicos, já que cada casa tinha seu próprio forno, o que também originava queixas: a queima de muita lenha; e o gasto de tempo usado pelas pessoas para os acender e manter. Assim, em 1531 o concelho estabeleceu a construção de "seys hornos en los lugares más convenientes y más proporcionados y en comarca donde puedan llebar los vezinos e moradores comarcanos a cocer su pan y que estos lugares señale la justicia e regimento" [Ordenanzas del Consejo de Gran Canaria (1531) (Sevilla, 1974), pp. 80-82].

${ }^{31}$ Barros, Henrique Gama, cit. (n. 2), IV, p. 117.

${ }^{32}$ Ver nota 27. Semelhante atitude, de mandar derrubar os fornos de pão construídos por particulares nas suas casas, também ocorreu em Granada, no início do século XVI [PADILLA Mellado, Lorenzo, Autos y pleito de derribo de hornos que cada vecino tenía fecho en su casa en alquerías de la vega de Granada y Valle de Lecrín, in Revista del Centro de Estudios Históricos de Granada y su Reino, 21 (2008), pp. 261-286; 22 (2010), pp. 211-242].

${ }^{33}$ Doc. 117, publicado por Carvalho, Maria José Pereira, cit. (n. 17), pp. 212-214. Ver ainda GONÇALVES, Iria, cit. (n. 16), p. 126. 
forno. [...] e cada molher pode cozer em forno ser dentro em sua casa e sua nora com ella. e a nora pode isso mesmo cozer o pam da sogra. e nom outra pessoa" ${ }^{34}$.

\section{DAS NORMAS PARA A CONSTRUÇÃO}

A liberdade de se poder construir fornos de pão, por certo, faria aumentar o seu número dentro do espaço urbano. Pelo contrário, sem a condição de livre construção, estas estruturas seriam mais escassas. Deveras, sabe-se que, nos séculos $\mathrm{XIV}$ e XV, o rei detinha apenas quatro fornos em Silves, mais quatro em Tavira e outros tantos em Faro, dois dos quais estavam dentro da vila e dois nos arrabaldes ${ }^{35}$. Em Marioga, no início do século XV, havia dois fornos de pão do Mosteiro de Alcobaça, tantos quanto existiam de poia na povoação da Coina, em meados do século XVI, pertencentes ao Mosteiro de Santos, da Ordem de Santiago ${ }^{36}$. Em 1508, o lugar da Silvã, parte da comenda de Marmeleiro, da Ordem de Cristo, tinha unicamente "buu forno da hordem poyeiro ao qual sohiam vijr cozer todollos moradores do dicto logo" 37 .

Associados ao número dos fornos de pão estariam, então, os danos provocados no ambiente urbano envolvente e, consequentemente, a necessidade das autoridades imporem medidas jurídicas para os acautelar. Ora, é precisamente por causa desta relação que apenas se encontram normas jurídicas para a construção dos fornos de pão nos costumes das povoações onde existia aquela liberdade construtiva.

\section{Normas medievais}

Os mencionados costumes de Alfaiates determinavam o seguinte: "Toto omine qui forno ó frauga de nueuo faga lo en tal logar que non faga mal a bodega. Qui paia metiere en casa ó feno en tal logar lo meta que non faga mal a otri, et si dano fizier a otri pectet alquel omine que lo fizier el dano [...] Todo omne que forno ó fragua fezier de nouo, en tal lugar lo fagar que non faza mal ad suo uizino"38. $\mathrm{Ou}$ seja, nesta vila, os fornos que de novo se construíssem não podiam fazer dano, nem às adegas, nem aos vizinhos, estabelecendo-se ainda que o dano não podia provir da acumulação de substâncias (palha ou feno) usadas para acender o fogo.

Se nestes costumes apenas se encontra uma disposição genérica -a de não provocar dano noutrem-, usualmente presente noutras cláusulas, noutros diplomas, e até, noutras culturas jurídicas, são, todavia, os costumes de Santarém, posteriores a 1347, que contêm a mais antiga restrição conhecida na documentação jurídica portuguesa sobre a construção de fornos.

${ }^{34}$ Tombos, cit. (n. 19), III, pp. 206-207, 275.

${ }^{35}$ Barros, Henrique Gama, cit. (n. 2), IV, p. 117; ANTT, Chancelaria de D. Afonso V, Livro 8, fl. 139r-139v (os "quatro fornos de poya nossos que nos auemos em nossa villa de Tauira" foram, em 1464, doados por D. Afonso V a Afonso Madeira).

${ }^{36}$ Gonçalves, Iria, cit. (n. 16), p. 458; MAta, Joel Silva Ferreira, A comunidade feminina da Ordem de Santiago: A comenda de Santos em finais do século XV e no século XVI. Um estudo religioso, económico e social (Porto, 2007), p. 224.

${ }^{37}$ Tombos, cit. (n. 19), VI, p. 58.

${ }^{38}$ Portugaliae, cit. (n. 9), pp. 808, 847. 
Nela se lê: "Dos que querem fazer fornos que am despaço. Custume he, de quem quiser fazer forno, de estar huum homem en geolhos en cima da comeeira e lançar huu arratal, e outro tanto fazer of forno aalen daquel forno, que esta na rua hu el, quanto for arratal. Assi se guarda" 39 . Ou seja, em Santarém, os novos fornos teriam de estar separados dos fornos existentes, sendo esse afastamento determinado pelo espaço percorrido por um peso, o arrátel, depois de ser lançado por um homem ajoelhado em cima da cumeeira do telhado do forno existente. Esta norma escalabitana, curiosa pelo método proposto, não foi caso singular, já que idênticas normas também se deparam na documentação de outras povoações. Para Évora, tal acha-se numa ordenação do rei D. Duarte, apregoada no dia 30 de abril de 1436, cuja vigência se estendia a toda a comarca: "Esta he a ordenança de como se ham de faser os fornos e fornalhas novamente em os lugares desta comarca. s. que o nom façam sem o primeiramente faser saber aos Juises e oficiaaes da cidade ou lugar por veerem se faz perjuiso a algua pessoa e se dello nom seguir odios e trabalhos aos oficiaaes e pobradores da terra. Porem vista hua contenda que em esta cidade foy antre Martim Vicente pedreiro e João Vicente moradores em a dita cidade a qual foy per esta cidade bem devulgado, e acordado que nenhum nom deve nem possa fazer forno em lugar que doutro forno possam a elle chegar com hum arratel de ferro o qual arratel ha de seer lançado de cima do telhado do forno que ja he feito. E asy ficou acordado e avido per ordenaçam, e asy foy julgado per sentença que o dito Martim Vicente fez esse o dito forno, e o fez, e por ficar em memoria o mandaram aqui escrever como som escriptas as outras ordenaçõoes. O qual arratel se ha de lançar aqui com hum giollo posto em hum cabeçal sobre o telhado do forno que ja feito he" ${ }^{40}$.

A determinação régia impunha, então, que a construção de novos fornos e fornalhas fosse precedida pela avaliação prévia dos juízes e oficiais das respetivas terras, de modo a verificarem se tais estruturas faziam ou não prejuízo a alguém. Acrescentava, ainda, um preceito já utilizado pelo concelho eborense na resolução de uma contenda sobre a construção destas estruturas: a distância mínima para se autorizar a construção de um novo forno seria fixada pelo lançamento de um arrátel de ferro, estando o lançador com um joelho assente na parte mais alta do telhado do forno existente. Para Lisboa, semelhante medida descobre-se numa compilação normativa emanada pela autoridade concelhia na segunda metade do século XV, debaixo do rótulo fforal dos fornos ${ }^{41}$. Contém o seguinte conteúdo: "Em esta parte que diz a fym da ley aos xbiij em rrezom do forno he custume da çidade de lixboa que forno de pam que Cada hũu quiser fazer novamente em ssua herdade deue de ser alongado do outro que ante hi algũu teuer quanto poder lançar hũu homem com a mãao huu arratell forforinho E este custume he Ja perescripto

\footnotetext{
${ }^{39}$ Costumes de Santarém publicados por Brandão, Zeferino, Monumentos e lendas de Santarém (Lisboa, 1883), p. 408.

${ }^{40}$ Doc. 23, em Documentos históricos da cidade de Évora, segunda parte (Evora, 1887), p. 55.

${ }^{41} \mathrm{O}$ termo foral significa, aqui, conjunto de normas jurídicas sobre uma atividade pública concreta e não carta de foro [PINTO, Sandra M.G., Em torno do foral medieval da almotaçaria de Lisboa, in Fragmenta Historica: História, Paleografia e Diplomática, 4 (2016), pp. 49-50].
} 
que a memorea dos homeens nam he em comtrairo. E os moradores de lixboa aJam liuremente tendas e fornos" 42 .

Tal como em Évora, parece que também em Lisboa o registo do costume foi posterior ao seu uso efetivo, encontrando-se aqui uma das fórmulas jurídicas correntemente usadas para certificar a sua antiguidade: era um costume tão antigo que a memória dos homens não o contrariava. $\mathrm{E}$, também aqui, o afastamento entre fornos era determinado pelo arremesso de um peso, neste caso um arrátel forforinho, lançado por um homem com a sua mão.

A norma lisboeta foi, depois, comunicada à ilha de São Tomé, aparecendo claramente invocada na carta de povoação outorgada por D. João II em 16 de dezembro de 1485 -isto é, cinco anos antes de o rei ter transferido todos os direitos dos fornos para o capitão-donatário, seguindo, como se viu, o critério adotado para as outras ilhas-, apesar de neste diploma se continuar a reafirmar a jurisdição régia destas estruturas de produção, tal como sucedia no Algarve ou noutras ilhas Atlânticas. Dizia então: "Outrosy nos por nosso Sennhorio tomamo pera nos todollos fornos de poya e fornalhas da dita ylha e que pesoa alguma sem nossa autoridade e liçemça os nam pode fazer. pero a nos apraz por fazermos merçee aos sobre ditos capitam e moradores della que qualquer vizinho della e morador os possa fazer. liuremente comtamto que dhuu forno ao outro nam aJa menos despaço que quanto huu homem possa lamçar com a mãão peso de huu aRatel. folforinho segumdo foral e custume da nossa cydade de lixboa e esto se emtemda des que em a dita ylha ouuerem pauoraçam Junta que com Rezam se possa e deua teer o dito foral e custume" ${ }^{33}$.

A similidade das normas de Santarém, Évora e Lisboa permitem atestar a existência de um costume medieval comum, cuja praticabilidade da metodologia prescrita pode ainda ter contribuído para que o mesmo fosse transmitido a outras povoaçōes portuguesas. Em concreto, este costume condicionava espacialmente a construção de fornos de pão, acabando também ela por limitar o número destas estruturas, bem como, os danos associados.

\section{Revogação das normas medievais}

Pouquíssimo tempo depois do fforal dos fornos ter ficado registado por escrito, o concelho da cidade de Lisboa solicitou a D. Afonso V, nas Cortes de Lisboa de 1478, a confirmação da sua alteração. A razão prendia-se com a falta de fornos que havia na cidade, consequência, precisamente, da existência do vetusto costume. Para tal invocaram uma determinação anterior feita pelos cidadãos e povo, a qual, segundo eles, tinha andado perdida: "E outro capitollo he este segue Senhor a çidade teem hũa Sentença e determjnaçam per çidadãaos e pouos a quall de muytos tempos he escondida e ora se achou per que mandam e hordenam que quallquer vezinho e morador da dicta çidade possa fazer forno e fornalha sem comtradiçom algũua nos lugares honde lhes prouuer tirando cassas sobradadas pede a dicta çidade vossa alteza que lhe mandees confyrmar a dicta Sentença e determynaçom que asy os dictos çidadãaos fezeram porque a çidade se sente Roubada dos que asy fornos teem

\footnotetext{
${ }^{42}$ Livro das Posturas, cit. (n. 5), p. 116.

${ }^{43}$ Doc. 200, em Descobrimentos cit. (n. 29), pp. 297-299.
} 
por serem poucos. Ao quall capitollo dey a rreposta que segue se tal sentença teem ou determjnaçom husem della quando per dirreito deuem" ${ }^{44}$. Com a anuência régia -imprescindível para se alterarem costumes antigos-, a capital do reino passou, então, a permitir a livre construção de fornos e fornalhas, em qualquer lugar ${ }^{45}$, determinando apenas que não fossem construídos nas casas sobradadas, ou seja, em edifícios com pisos superiores.

Em 1529, esta postura foi novamente modificada pelo concelho. Continuouse a denegar o vetusto costume, mantendo-se assim a liberdade construtiva, mas estabeleceu-se agora que o fumo dos novos fornos não podia incomodar os vizinhos, sugerindo-se a construção de chaminés ou outros resguardos: "Titollo dos ffornos de pam que hos possa cada hum ffazer homde quiser - ffoy Acordado pellos Sobre ditos por quamto por pustura amtigua hera de fesso que nam ffizessem fornos depoyas senam allomguado hum do outro djstamçia de hum ARatell ffor forinho ho que aesse tempo Era bem ordenado plla pouoação da cidade nam ser tam grande senam aver hy tamta neçessidade delles e ora por ha dita çidade vir em gramde creçimemto he Nam Aver hy tamtos ffornos que Mais Nam Sejam neçessarios ffoy detriminado que cada hum podese ffazer ffornno depoya homde quisese Sem se midir distamçia allgua de hum ao outro com tanto que nam ffaçam com ${ }^{\text {ho }}$ fumo deles nojo aos vizinhos oque podera evitar fazemdolhe chumine ou outros Resguardos Segumdo ho direito Em tal caso manda E porem jsto senam emtemdera nos ffornos jaa ffeitos por que nesses seguardara apostura amtigua Somente avera llugar nos que nouamente sse fizerem em lluguares homde Nam Estam outros Amtiguos" 46.

Mas em 6 de fevereiro de 1548, aquando de nova confirmação régia desta postura lisboeta, D. João III acrescentou que as tais chaminés preceituadas deveriam ser altas: "Eu el Rey faço saber a vos vereadores e procurador e procuradores dos mesteres desta minha cidade de lixboa que Eu sam informado que os vereadores que foram o ano de mil bos xxix fizeram huuã pustura na qual se comtinha que por huuã pustura amtigua era defezo que senam fizesem fornos de poya senã afastado hũu do outro de distamcia quamto huuã pessoa podesse lamçar hũu aRatel forforinho $E$ isto por ao tal tempo a pouoaçam naão ser taão gramde E naão aver ay tamta necesidade dos dictos fornos e por a cidade yr ja em tam gramde crecimento e naão aver tamtos fornos como heram necesarios foy por elles determjnado e feita pustura que cada hũu

${ }^{44}$ Doc. 420, em Livro dos Pregos (Lisboa, 2016), p. 543. Ver ainda Rodrigues, Maria Teresa Campos, Aspectos da administração municipal de Lisboa no século XV (Lisboa, 1968), pp. 101-102.

${ }^{45}$ Contrariamente, em 20 de abril de 1509 , devido aos abusos e prejuízos relatados, o rei Fernando II de Aragão fixou o espaço de 60 casas como a distância mínima que deviam ter os novos fornos de pão relativamente aos existentes na cidade de Valencia: "provehim, declaram, statuhim é ordenam, que cascun forn de coure pá en dita Ciutat construit ó construidor en sdevendior, haja e tinga al menys sexanta cases de limits entorn, dins los quals limits altre forn no puga estar ni esér construit, ó edificat" (proveemos, declaramos, estabelecemos y ordenamos, que cada horno de cocer pan construido en dicha Ciudad, ó que se construya en lo sucessivo, haya e tenga á lo menos sessenta casas de limite en contorno, dentro cuyos limites no pueda haber ni ser construído ó edificado outro horno) [Tratado de los derechos y regalias que corresponden al Real Patrimonio en el Reyno de Valencia (Valencia, 1786), III, pp. 119-121].

${ }^{46}$ Arquivo Municipal de Lisboa - Núcleo Histórico (=AML-NH), Chancelaria da Cidade, Prólogo de Posturas Antigas, doc. 5, fl. 6r-6v. 
podese fazer forno de poya onde quisese sem se medir a dita distamcia de $h$ u ao outro $e$ isto naão fazendo con ofumo delles nojo aos vizinhos o que se poderia hevytar fazemdo chamines ou outros Resguardos E que isto senã entendão nos fornos que ja erã feitos por que nisto se guardarya a pustura amtigua E que somente averya lugar nos que novamente se fizesem E ora por allguus justos Respeitos que me ayso mouem ey por bem que daqui em diante senã guardem as ditas pusturas nem se use dellas e mando que quallquer pessoa posa fazer forno sem aver Respeito de distamcia allgunã que ajaa dallguus fornos que estiuerem feitos a outros e isto asy nos lugares omde ja estiverem ffornos feitos como nos que se fizerem de nouo $E$ os ditos fornos se farã em maneira que com ho fumo delles senã faça nojo aos vizinhos fazendo lhe chamjnes alltas" ${ }^{47}$.

A eliminação da restrição espacial à construção de fornos de pão em Lisboa, com certeza, provocou um acréscimo do seu número. João Brandão, em 1552, estimou existirem cerca de 500 fornos, os quais aqueciam 7,8 ou 10 vezes ao dia, além de outras fornalhas que coziam pão mais mimoso em média 5 vezes ao dia ${ }^{48}$. Se estes valores parecem um pouco excessivos, dado que Nicolau de Oliveira em

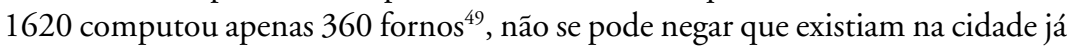
numerosos fornos de pão a cozer e a fumegar várias vezes ao dia. Analogamente, outras cidades solicitaram a autorização régia para revogar os seus costumes antigos. Por alvará de 17 de março de 1537, Évora deixou de aplicar a limitação espacial na construção de fornos, mandando-se "que daqui em diante toda pessoa possa fazer nesta Cidade fornos em qualquer parte e logar onde os quizer e poder fazer" ${ }^{50}$.

Outro caso depara-se em Elvas. Apesar de não se ter encontrado nenhum documento ou referência medieval que indiciasse a vigência do costume -pese embora a indicação de que o costume eborense se aplicava a toda a comarca, onde se inseria Elvas-, sabe-se que no século XVI o procurador da cidade solicitou ao rei a revogação de um costume muito semelhante, não de Évora, mas de Lisboa, o que, ao fim ao cabo, permite atestar a sua vigência anterior. A proximidade costumeira à norma da capital é verificada pela referência concreta ao tipo de arrátel usado, o folforinho. Mas também o fundamento utilizado no pedido foi o mesmo que tinha sido invocado em Lisboa, ou seja, a falta de fornos de pão na povoação.

Assim, em 17 de janeiro de 1548, o rei assentiu à alteração do direito local elvense através de alvará: "Eu elRei faço saber a quamtos este meu alluara vire [m] q[ue] martim roiz como procurador que he do c [oncelh]o da cidade delluas me fez sua petição de que o trellado he o seguinte: - Diz martim roiz como procurador q[ue] he da çidade delvas que na dita çidade ha poucos fornos de cozer pão semdo a pouação gramde e que te[m] muita necesidade daher mais fornos e por na dita çidade se vsar

${ }^{47}$ AML-NH, Chancelaria Régia, Livro dos Regimentos dos Vereadores e Oficiais da Câmara (Livro Carmesim), doc. 35, fl. 45 [parcialmente publicado em Documentos do Arquivo Histórico da Câmara Municipal de Lisboa: Livros de Reis (Lisboa, 1962-1964), VI, p. 42] e cópias, no mesmo arquivo, na Chancelaria da Cidade, Livro $1^{\circ}$ de Posturas, doc. 29, fl. 44r-44v; Cópia do Livro das Posturas da Cidade de Lisboa, doc. 81, fl. 107r-107v; Livro 2o da Casa da Almotaçaria, doc. 20 , fl. $56 \mathrm{v}-57 \mathrm{v}$.

${ }^{48}$ Brandāo, João, Grandeza e abastança de Lisboa em 1552 (Lisboa, 1990), pp. 87-88.

${ }^{49}$ Oliveira, Nicolau de Oliveira, Livro das Grandezas de Lisboa (Lisboa, 1620), fl. 95v.

${ }^{50}$ Item 1138 em Os originais do cartório da Câmara Municipal de Évora, in A cidade de Évora, Boletim, 22-24/48-50 (1965-1967), p. 279. 
huu custume amtiguo deste Rejnno de que em allguas partes ha posturas que se não faça forno a par de out [r]o forno tanta distançia como huu home [m] poode atirar co[m] huu aratel folfurinho se leixão de fazer muitos fornnos e he gramde opresão do povo vsarse o dito custume porque allgu[m] as pesoas impede[m] q[ue] outra p[es] s[o]a os não fação pede a $V$. A. que avemdo respeito ao sobredito aja por bem pasar prouisão pera que na dita çidade se não vse do dito custume amtiguo e que que[m] quiser fazer fornno que o posa fazer posto que na [m] aja a dita distamcia de huu forno ao out $[r]$ o e reçebera merce. - E visto seu requerime[n] to e avemdo respeito ao que na dita petição diz ey porbem e me praz que na dita çidade delluas se na [m] vse daqui e[m] diamte do custume amtiguo de que na dita peteção faz me [n] ̧̧ão, e que se[m] embarguo delle qual[que]r pesoa que na dita çidade quiser fazer fornno de cozer pão o posa fazer posto que na [m] aja tamta distancia de huu forno a out [r]o como huu home [m] poode atirar co $[\mathrm{m}]$ huu aratel folfurinho. noteficoo asj a quaisq[ue]r justiças a que o conhecimto disto pertencer e lhe mando q cuprão e fação imtrame[n] te cumprir este allu[ar] a como se nele co[n] them o q[ua]l ey por be[m] q[ue] valha e tenh a forsa e vigor como se fosse carta feita e $[\mathrm{m}]$ meu nome por my asynada e pasada p[o]r minha chamcelria posto q[ue] este na [m] seja passado p[o]r ella sem embargo das ordenaçois do segumdo liuro que o comtr[ari]o dispóem" ${ }^{51}$.

\section{Normas modernas}

Como se viu, na revogação dos costumes medievais de Évora ou de Elvas, e diferentemente ao que aconteceu em Lisboa, não ficou determinada nenhuma outra imposição (resguardos ou chaminés) para a construção de novos fornos. Não obstante, outras povoações começaram a impor essa mesma obrigatoriedade nas suas posturas, sob pena monetária para os infratores. Veja-se três exemplos.

Em 1603, a câmara da Coimbra estabeleceu o seguinte: "Aos Vinte e seis de Julho de seis centos e tres Annos nesta Camara se acordou por ser em bem publico do Pouo, \& da Vezinhanca dos moradores da Cidade asim dos Arabaldes como dalmedina dos muros adentro que todos os fornos asim de poia como de louça tenhaó chamines altas, de maneira que defumassem por sima dos telhados de toda, E qual quer uizinhanca onde estiuerem situados sem se poder fazer preiuizo a elles como o fumo dos ditos fornos por ser muito preiudicial asim pera a Saude do pouo, como pollo damno $q$ fazem nas familias, E cazas dos uezinhos pelo que Acordaraó E asentaraó que da publicação deste em diante nenhua pessoa de qual quer calidade E condisaó que seia tiuer os ditos fornos adentro dos muros da Cidade façaó alevantar, E aleuantem dentro de quinze dias as ditas chamines, em altura que naó façaó o dito prejuizo, a qual sera uista pelos Juizes do officio dos pedreiros, prezente o procurador da Cidade, Sob pena de des cruzados pagos da cadea a metade pera a cidade E a outra pera catiuos E acuzador, alem diso que naó possaó usar dos ditos fornos, nem cozer nelles, nem louca, nem couza alguã de q mandaraó fazer este acordo, E assento que se lancaria no liuro grande das posturas" 52 .

A medida tinha aplicação, já não apenas sobre os novos fornos, mas também

${ }^{51}$ Doc. em Revista Lusitana, 11 (1908), pp. 65-66.

${ }^{52}$ Doc. publicado por Carvalho, J.M. Teixeira, A cerâmica de Coimbra (Séculos XVI e XVII), in Revista da Universidade de Coimbra, 6 (1917), p. 455. 
sobre os existentes, e todas as pessoas que tivessem fornos de pão de poia (ou de louça) ficaram obrigadas a levantar sobre eles uma chaminé alta, para que o fumo saísse por cima dos telhados dos vizinhos.

Também, nas posturas de Tomar, de 1607 se encontra: "Toda a pessoa que tiver forno de poia ou de louça, e os fornos dos saboeiros, farão chaminés deles de tanta altura de 6 palmos de craveira por cima das mais altas casas que ao redor estiveram, ou de fronte, não sendo as ditas casas de 2 sobrados sob pena de $3 \$ 000$ réis" 53 . Ou seja, para além da obrigação de se construir chaminés nos fornos de poia (como nos de louça e dos saboeiros), quantificava-se a altura que aquela estrutura deveria subir sobre os telhados das casas vizinhas (6 palmos, cerca de 1,32 metros).

Já as posturas de Leiria, de 1625, contêm duas normas sobre o assunto: “Outro si asentarão por postura que todas as pesoas que tiverem fornos de poya de pam os mandem aquentar e uzem delles, cozendo e poyando conforme ao costume desta cidade. E tendo-os sempre prestes para isso e o não querendo asim fazer os derribem. E fazendo o contrario pagaram de pena quinhentos reis. E alem da dita pena qualquer pesoa podera fazer fornos, a par dos tais fornos que não cozerem, sem o poderem defender. E bastara para isso estarem tres mezes sem cozer"; e "Outro si acordaram e puzeram por postura que nenhuma pesoa que tiver fornos asim de poya, como de lousa vidrada, $e$ por vidrar, e de telha tijollo, os quais com o fumo fazem munto perjuizo. Por respeito de não terem chamines que nenhuma pesoa posa ter forno que coza qualquer das ditas couzas nesta cidade e arrabalde, sem ter chamine tam alta que não fasa nojo o fumo. E quem quer que cozer em qualquer dos ditos fornos sem ter a dita chamine pagara de pena dois mil reis para o conselho e quem os acuzar. E mais ser-lhe ha por justissa mandado deribar o tal forno. E a altura da chamine sera aquella que os almotaseis lhe asignarem, segundo em que forno estiver, porque huma parte sera nesesaria mais alta que em outra" ${ }^{4}$.

Ou seja, nesta vila, se os fornos de poia não estivessem em uso por mais de três meses, teriam de ser derrubados. Porém, dava-se a possibilidade de qualquer outra pessoa construir novos fornos próximos dos desativados para, assim, os substituir, ao mesmo tempo que se retirava dos anteriores proprietários a capacidade de se oporem à construção dos novos fornos. Já a altura das chaminés sobre os fornos de poia (como de louça e de telha), seria determinada pontualmente pelos oficiais almotacés, tendo em vista a localização concreta das estruturas.

${ }^{53}$ Anais do Municipio de Tomar, Volume IV (1581-1700) (Tomar, 1968), p. 71. Parece, contudo, que esta postura não foi acatada pelos donos dos fornos das louças, impondo-se, no século XVIII, novo levantamento das chaminés: "Na Câmara de 10 de Outubro de 1792, logo pelo Procurador do Concelho foi dito que, determinando as Posturas que as chaminés dos fornos serão mais altas que os telhados das casas vizinhas, e ainda dos mesmos edifícios, pelo perigo de incêndios que podem nascer dos mesmos fogos das chaminés, e não cumprirem assim os donos dos fornos das louças, aonde ardia mais lenha e por mais tempo do que nos de pão, por cujos motivos requeria fossem estes notificados para, dentro de 8 dias, levantar as ditas chaminés, com as penas estabelecidas na Postura, aumentando-se-lhe as mesmas em caso de contumácia" [Anais do Município de Tomar, Volume VI (1771-1800) (Tomar, 1970), p. 324].

${ }^{54}$ Posturas publicadas por Lopes, Fábio Morgado, Posturas de Leiria (séc. XVI-XIX): Contributo para o estudo da administração municipal em Portugal (Mestrado, Universidade de Coimbra, 2003), pp. 595 e 611. 


\section{Dos AFASTAMENTOS ÀS CHAMINÉS: ASPETOS JURÍDICOS E AMBIENTAIS}

O elenco normativo exposto não pretende ser exaustivo, mas revela-se suficiente para aferir as duas medidas regulatórias usadas pelas autoridades locais portuguesas de modo a acautelar os potenciais danos provocados pelos fornos de pão no ambiente urbano envolvente. Uma, provavelmente, apenas usada nas povoaçôes de maior dimensão durante o período tardo-medieval ${ }^{55}$, baseava-se no afastamento dos fornos; a outra, adotada também por povoações de menor dimensão, no período moderno, impunha a obrigatoriedade de serem construídas chaminés. Analise-se, então, cada uma destas medidas.

Não parece ser fruto do acaso a similitude normativa encontrada em Santarém, Évora, Lisboa e Elvas. Todavia, a inexistência de melhores dados ou de equiparações jurídicas invalida o cabal conhecimento sobre a origem deste costume, algo que apenas se pode conjeturar através das diversas pistas deixadas pelas próprias normas.

Comece-se pelo objeto a atirar. Este era, em Santarém um arrátel; em Évora um arrátel de ferro; e em Lisboa, como em Elvas, um arrátel forforinho. $\mathrm{O}$ termo português arrátel deriva do árabe fonético ar-rațl, que por sua vez era a forma aramaica do grego (lítra), equivalente à libra romana ${ }^{56}$. Em Portugal, o arrátel foi uma das medidas principais do sistema de pesagem, assumindo a mesma preponderância que a libra desempenhou noutros países europeus. Com a reforma manuelina -que uniformizou os diferentes sistemas de medição do reino-, o arrátel passou a dividir-se em 16 onças, ainda que outrora os seus submúltiplos pudessem variar, encontrando-se arráteis com divisões entre as 12,5 onças e as 64 onças. Documentos medievais comprovam que havia marcas ou padrões de Lisboa e de Santarém, como também pesos de quatro, dois, um, meio e quarto de arráteis. Existiam, ainda, tipos específicos de arráteis: o comum ou mourisco de 16 onças, também usado em Lisboa para pesar a carne (c. 459 gramas); o da carne, pesando quatro vezes um arrátel mourisco, ou seja, 64 onças (c. 1,836 quilogramas); o de peso velho de 14 onças, depois somente usado na Casa da Índia (c. 402 gramas); e finalmente o forforinho ou folforinho, que derivava igualmente dos pesos árabes, em particular o rațl fulfult -derivado da palavra fulful, que significa pimenta, e

${ }^{55}$ De facto, Lisboa, com cerca de 103,6 hectares, Santarém, com cerca de 45 hectares, e Évora, com cerca de 50 hectares, eram as povoaçōes portuguesas com maior dimensão e, eventualmente, com maior densidade populacional. Seguia-se o Porto, com cerca de 44,5 hectares, e Leiria, com cerca de 30 hectares [MARQues, A.H. de Oliveira; GonÇALVES, Iria; Andrade, Amélia Aguiar (org.), Atlas de Cidades Medievais Portuguesas (Séculos XII-XV) (Lisboa, 1990), pp. 23, 51, 55, 65, 83].

${ }^{56}$ Ashtor, Eliyahu, Mak yil - 1. In the Arabic, Persian and Turkish Lands, in The Encyclopaedia of Islam, New Edition, 12 vols. (Leiden, 1986-2004), VI, pp. 117-121; SтUмPF, Gerd, Litra, in Brill's New Pauly: Encyclopedia of the Ancient World: Antiquity (Leiden, 2005), VII, p. 727. 
por isso este peso era usado para pesar especiarias ${ }^{57}$-, o qual pesava menos um quarto do arrátel mourisco, ou seja, 12 onças (c. 344 gramas) ${ }^{58}$.

Ora, como o peso a ser atirado corresponde, sem sombra de dúvida, a uma influência islâmica e como a norma aparece em povoações que tiveram uma forte dominação muçulmana, será que a própria norma corresponde, também ela, a um legado islâmico? Ainda que as circunstâncias permitam sugerir esta ligação, a verdade é que a ausência de dados jurídicos comparativos acaba por afastar a suposição. De facto, nos dois compêndios de fiqh al-bunyān ou jurisprudência da construção islâmica, com maiores aproximaçōes ao Al-Andaluz -e que, por isso, mesmo permitem verificar semelhanças ao nível da cultura construtiva-, não existem formalidades semelhantes ou aproximadas, encontrando-se apenas a proibição de se provocar danos a outrem com o fumo dos fornos ${ }^{59}$.

Se pelo arrátel não se retira grandes conclusões, atente-se, agora, à própria ação de atirar o peso. No Direito medieval português, em especial nas Ordenações Afonsinas de 1446, encontra-se um preceito para a ação de nunciação de obra nova através do lançamento de pedras. Este jactus lapilli tinha origem no Direito romano ${ }^{60}$, estando ainda descrito na grande obra legislativa de Alfonso X de Castela, as Siete Partidas ${ }^{61}$, a qual fez parte do ordenamento jurídico medieval português, quer como direito subsidiário, quer como fonte direta na constituição de vários títulos da compilação legislativa afonsina ${ }^{62}$. Mas é a própria norma das Ordenações que esclarece que tal ação aplicava-se "segundo usança de cada huum Luguar" ou "segundo Direito, e usança da terra" ${ }^{3}$, levando a supor que a prática do lançamento de pedras pudesse existir há bastante tempo em algumas povoações portuguesas. Alem disso, esta prática jurídica de natureza simbólica, com carácter público, entrecruza-se, naturalmente, com a traditio corporalis, usada na transferência de propriedades imobiliárias ${ }^{64}$. Esta última aparece no universo

${ }^{57}$ Serra, Pedro Cunha, O "arrátel folforinho", in Revista Portuguesa de História, 13 (1971), pp. 139-144.

${ }^{58}$ ReI, António, Pesos e medidas de origem islâmica em Portugal, Notas para o seu estudo (Évora, 1998), pp. 8-9; LOPES, Luís Seabra, Sistemas legais de medidas de peso e capacidade, do Condado Portucalense ao século XVI, in Portvgalia, Nova Série, 24 (2003), pp. 113-164.

${ }^{59}$ Uma obra foi escrita por um jurista de Tudela (Espanha), conhecido por Ibn al-Imām, no século X; a outra por um mestre construtor que servia como especialista judicial em Tunes (Tunísia), conhecido como Ibn al-Rāmī, no século XIV. Ver concretamente: Des fours, bains, boutiques de forgerons et de tanneurs nouvellement établies - De la suppression de celles qui nuisent, em BARBIER, Droit Musulman: des droits et obligations entre propriétaires d'héritages voisins, in Revue Algérienne et Tunisienne de Législation \& de Jurisprudence 16 (1900), pp. 101-102; e Discourse on the harm of smoke and the judgment on it, em MuHAMAD, Mohd Dani, Rules for compact urbanism, Ibn al-Rami's $14^{\text {th }}$ cemtury treatise (2017), pp. 38-40.

${ }^{60}$ D. 39, 1, 5, 10 [Corpus Iuris Civilis, Volumen primum: Institutiones, Digesta (Berolini, 1889), p. 592].

${ }^{61}$ Partidas, 3, 32, 1 [Las Siete Partidas del Rey Don Alfonso El Sabio (Madrid, 1807), II, p. 770].

${ }^{62}$ Domingues, José, O elemento castelhano-leonês na formação do direito medieval português, in Cuadernos de Historia del Derecho, 21 (2014), pp. 218-224.

${ }^{63}$ Ord. Afonsinas 3, LXXX, 5 [Ordenaçōes Afonsinas (Lisboa, 1984), III, pp. 310-311].

${ }^{64} \mathrm{~A}$ traditio corporalis funcionava do seguinte modo: o transferente entregava ao adquirente 
português a partir da segunda metade do século XIII, a qual, apesar de também se fundamentar no Direito romano, derivou antes da presença de usos e costumes populares, não escritos, de origem germânica ${ }^{65}$.

Nesse sentido, é dentro do universo jurídico da Europa do norte que se vão encontrar várias cerimónias e práticas de lançamentos de objetos (martelos, dardos, lanças, flechas), quer para fixar alguma extensão de território, quer para estabelecer domínios de propriedade, quer para determinar distâncias espaciais. Afinal, a própria mão representava simbolicamente a força física e pessoal do homem, tornando-se por isso sinal do seu poder, da sua jurisdição ${ }^{66}$. Dos muitos exemplos possíveis, citem-se dois. Na cidade de Eslinga em 1306, um moleiro de azenha estabelecia o seu espaço de domínio de pesca através do arremesso do seu machado, o mesmo com que tinha construído a sua azenha, para montante e jusante dela ao longo do curso de água. Em 1366, o concelho de Minden com o bispo concordaram em alargar o fosso da cidade em volta de toda a cerca, uma distância correspondente ao arremesso de um peso de chumbo de uma libra, lançado por um homem robusto, de pé, posicionado em cima do muro da cidade ${ }^{67}$.

Dada a similitude de preceitos, pode-se, então, supor que o preceito que se encontrou descrito nas normas medievais portuguesas, para determinar o afastamento entre fornos, apoiou-se ou foi inspirado em tradiçôes, usos e costumes populares trazidos pelos povos no norte europeu, que chegaram ao território português com ou após a Reconquista cristã. Aliás, esta mesma herança pode ter ainda influenciado o modo como o infante D. Pedro com o concelho de Coimbra, em 1437, fixaram o espaço do caneiro real -uma área marcada com estacas definindo a zona de pescaria de direito real- no rio Mondego: "buum tiro debeesta aso aponte se outro tanto acima da ponte Eesto por proveito della" ${ }^{68}$. Em todo

objetos que simbolizassem a coisa a transferir, sendo a entrega recebida em mãos. No caso de prédios urbanos o primeiro entregava elementos do edifício como a chave, uma porta, uma telha, e o segundo tocava com a sua mão nos elementos materiais que compunham as estruturas construídas (pedra, madeira, telhas), abria e fechava as portas e janelas. No caso de prédios rústicos os elementos a serem entregues eram pedras, torrão de terra, molho de vides, porção de milho ou ramo de árvore, com o respeito toque pelas mãos nas respetivas espécies vegetais que compunham o fundo produtivo.

${ }^{65}$ MonCADA, Luís Cabral, $A$ «traditio» e a transferência da propriedade imobiliária no direito português (séculos XII-XV), in Boletim da Faculdade de Direito da Universidade de Coimbra, 6 (1920-1921), pp. 472-496; SÁNCHEZ Domingo, Rafael, Traditio: Rito, símbolo y título en la transmissión de la tierra, in Glossae, European Journal of Legal History, 12 (2015), pp. 757-781.

${ }^{66}$ CHassan, Joseph Pierre, Essai sur la symbolique du droit, précédé d'une introduction sur la poésie du droit primitif (Paris, 1847), pp. 113-119.

${ }^{67}$ MichelET, Jules, Origines du droit français, cherchées dans les symboles et formules du droit universel (Paris, 1837), pp. 75-77 [citando GRIMM, Jacob, Deutsche Rechtsalterthümer (Göttingen, 1828), pp. 58, 62].

${ }^{68}$ Doc. 34, publicado por Pimenta, Belisário, As cartas do Infante D. Pedro à Câmara de Coimbra (1429-1448), in Arquivo de História e Bibliografia, 1923-1926, Volume I (Lisboa, 1976), p. 142. Inúmeros exemplos, do período moderno, confirmam o uso da medição de distâncias através de tiros de pedra, de besta, de espingarda, e até de outras armas de fogo, como bombarda, arcabuz, mosquete, peça de artilharia, berço, falcão [entre outros, ver PIMENTEL, Luís Serrão, Arte Prática de Navegar e Regimento de Pilotos repartido em duas partes (Lisboa, 1681), pp. 211, 214, 219, 224, 238, 252, 265, 275, 339]. 
o caso, o lançamento de objetos, enquanto forma de definir intervalos espaciais, encontrava ainda validação na cultura religiosa cristã, já que duas distâncias surgem descritas no texto sagrado: o tiro de arco (Génesis, 21:16) e o tiro de pedra (Lucas, 22:41). Assim sendo, qual seria, em concreto, o espaço possível entre fornos? A inexistência de estudos metrológicos específicos sobre distâncias obtidas através de lançamentos e tiros não permite obter-se uma equivalência rigorosa ${ }^{69}$. Porém, é crível que o arremesso de um objeto abaixo dos 500 gramas tivesse um alcance limitado entre os 25 a 30 metros $^{70}$. Possivelmente, a distância seria ligeiramente diferente entre Lisboa/Elvas e Santarém ou Évora, não apenas porque o peso a atirar era distinto, como também, porque na capital o arremesso era feito apenas com a mão, ao passo que nas últimas povoações especificava-se que o lançamento deveria ser executado por um homem ajoelhado em cima do telhado.

A distribuição dos fornos de pão no espaço urbano permitiria, então, minimizar o impacto dos danos que estas estruturas provocavam na vizinhança direta. Mas, note-se que nenhuma das normas medievais refere explicitamente quais eram os danos ponderados. Presume-se, então, que estes seriam o risco de incêndio e a emissão de fumos (que provocaria a poluição do ar e o enegrecimento de edifícios e objetos).

Todavia, só para o risco de incêndio é que se encontraram outras medidas preventivas, o que leva a supor que, por esta altura, seria esta a principal causa ${ }^{71}$. De facto, em 1394, a vereação de Lisboa estabeleceu uma Ordenacom dos fumeiros da sardinha, porque tinham sido avisados de "que alguas pessoas faziam ora nouamente fumeiros de sardinhas na dicta çidade em lugares que os numca ouuera e que eram muy perigosos", proibindo e existência de mais destes fumeiros e o aumento dos existentes, e, em 1442, uma Ordenaçom do foguo, impedia fazer-se "fogo nas rruas publicas e becos e sobreloJeas", com exceção dos "lareyros com caruom" nas ruas e becos e das "sobrelojeas que tem chumjnes"72.

Já sobre a poluição do ar devido aos fumos dos fornos nenhuma medida jurídica se achou na documentação medieval. Encontrou-se somente um caso particular, onde os almotacés e homens-bons de Santarém, em 1355, foram inspecionar uma fornalha que Andreu Joanes estava a construir na sua casa " $a$ par do Adro [da igreja] de Santa Cruz", acabando por embargá-la, porque "a ditta

${ }^{69}$ Somente, Marques, A.H. de Oliveira, Pesos e Medidas, in Dicionário de história de Portugal (Lisboa, 1984), V, p. 68, refere que o tiro de besta correspondia à clássica milha e equivalia a 200 metros ou mais.

${ }^{70}$ Seguindo também a opinião de LoPEs, Luís Seabra, cit. (n. 58), p. 126.

${ }^{71}$ As medidas preventivas contra incêndios foram, aliás, muito comuns por toda a Europa medieval, pelo facto dos edifícios serem extremamente combustíveis [SLATER, Terry R.; PINTO, Sandra M.G., Building regulations and urban form. An introduction, in Building Regulations and Urban Form, 1200-1900 (Oxon, 2018), pp. 7-9]. Ver ainda GómEz Rojo, María Encarnación, Historia juridica del incendio en la Edad Antigua y en el ordenamiento medieval castellano: Implicaciones urbanisticas y medioambientales, in REHJ., 33 (2011), pp. 347-361; A MESMA, Precedents de la legislació mediambiental. Repressió penal i prevenció urbanística dels danys produïts pel foc en algunes fonts del dret aplicades a Cataluya durant l'Edat Mitjana, in Revista de Dret Històric Català, 11 (2011-2012), pp. 97-145.

${ }^{72}$ Livro das Posturas, cit. (n. 5), pp. 123-124 e 15-16. 
Igreja recebia grande danno por a ditta fornalha mandar todo o fumo para a ditta Igreja", defumando-lhes as imagens e os ornamentos ${ }^{73}$.

Pode-se, então, pensar que durante o medievo, a poluição do ar decorrente dos fumos dos fornos não faria ainda parte dos problemas de salubridade, pese embora a ideia corrente de que as epidemias tinham origem nos maus cheiros e na corrupção dos ares. Mas tal contaminação atmosférica, supunha-se, tinha como causa primeira os miasmas que saíam das esterqueiras, das imundices e das águas residuais $^{74}$, não sendo ainda ateada pelos fumos da combustão. Afinal, várias doenças eram tratadas usando a queima de ervas, alimentos e animais, fosse através da fumigação ou pela aplicação das cinzas ${ }^{75}$. Mais, quando ocorria algum surto de peste (como aconteceu em Lisboa, em 1492) as casas eram mandadas lavar com vinagre e defumar com alecrim, purificando todo o ar da cidade com "foguos d'alecrim per todallas portas e casas"76. Por tudo isto, intui-se que, nesta altura, o fumo era reputado como remédio e benefício, tal como surge exemplarmente relatado numa descrição seiscentista de Inglaterra, onde se lê que, outrora, o fumo no interior das habitaçōes servia não apenas para afastar doenças dos moradores, como também para endurecer as madeiras das casas $^{77}$.

Esta circunstância cruza-se, aliás, com dois aspetos que se deduzem da es-

${ }^{73}$ ANTT, Colegiada de Santa Cruz da Ribeira de Santarém, Maço 1, doc. 60. Ver BeIranTE, Maria Ângela, Santarém Medieval (Lisboa 1980), p. 231.

${ }^{74}$ Por exemplo, em Évora, proibia-se lançar lixo nas ruas da cidade, mas somente nas esterqueiras, "Porque das çogidades e estercos e cousas podres e nojosas e ffumos que sse dellas fazem nos logares recreçem muitos danos e doorees aos corpos e ainda pareçe mall os logares onde sse tall coussa conssente" [Os regimentos, cit. (n. 7), pp. 66]. Sobre as medidas sanitárias, ver MouRA, Álvaro de Mendonça Gomes de, Alguns séculos de administração sanitária, Subsidios para a sua história na cidade do Pôrto e no seu termo (Lisboa, 1945); TAVARES, Maria José Ferro, A política municipal de saúde pública (séculos XIV-XV), in Revista de História Económica e Social, 19 (1987), pp. 17-32; BeIranTE, Maria Ângela, Saúde pública em Évora durante a baixa Idade Média, in $O$ ar da cidade, Ensaios de história medieval e moderna (Lisboa, 2008), 223-233.

${ }^{75}$ Ver por exemplo as receitas do Thesaurus Pauperum, ou da Summa de Conseruanda Sanitae, de Pedro Hispano [publicadas por Pereira, Maria Helena da Rocha, Obras médicas de Pedro Hispano (Coimbra, 1973)].

${ }^{76}$ Carta régia de 16 de outubro de 1492, em Elementos para a Historia do Municipio de Lisboa (Lisboa, 1882-1911), I, pp. 461-462. Semelhantes medidas foram recomendadas no Regimento proveytoso contra ha pestenença impresso em 1495/96 em Lisboa [publicado por RoQUE, Mário da Costa, As pestes medievais europeias e o "Regimento proueytoso contra ha pestenença", Lisboa, Valentim Fernandes (1495-1496). Tentativa de interpretação à luz dos conhecimentos pestológicos actuais (Paris, 1979), pp. 324-325, 428]. A queima de outras ervas e madeiras de bons cheiros, como zimbro, cedro, acipreste, oliveira, esteva, vides, pinho, murta e aroeira, era também aconselhada, cujas fogueiras deveriam ser acesas de manhã e à noite no verão e a todas as horas no inverno [Advertencias dos meios que os particulares podem usar para preservar-se da peste... II Edição, A que se ajunta o Opusculo de Thomaz Alvares e Garcia de Salzedo sobre a peste de Lisboa em 1569 (Lisboa, 1801), pp. 2-3, 12].

${ }^{77}$ A descrição é de William Harrison, de 1577: "For as the smoke in those daies was supposed to be a sufficient hardning for the timber of the house; so it was reputed a far better medicine to keepe the goodman and his familie from the quacke or pose, wherewith as then verie few were oft acquainted' [Holinshed's Chronicles of England, Scotland and Ireland in six volumes, Vol. I England (London, 1807), p. 356]. Ver ainda Brimblecombe, Peter, The big smoke. A history of air pollution in London since medieval times (Oxon, 2011), p. 35. 
pecificação do lançamento do peso ser feito "en cima da comeeira", ou "cima do telhado do forno”, presente nas normas de Santarém e de Évora. O primeiro aspeto percebe-se pela referida menção, ou seja, os fornos deveriam estar sob uma estrutura construída telhada, quer fosse um telheiro, um coberto, um alpendre, ou até, um edifício fechado, a chamada casa do forno, que diversas fontes documentam ${ }^{78}$. $\mathrm{O}$ segundo aspeto retira-se pela omissão das mesmas normas. Estas casas do forno não teriam ainda condutas exteriores para expelir os produtos da combustão, ou seja, chaminés. Os fumos deveriam, então, sair pelos vãos existentes, desde logo a porta de entrada ou outras frestas nas paredes, por pequenas aberturas na cobertura, ou por entre as telhas, ainda que guiadas por resguardos interiores, seguindo o mesmo princípio de exaustão utilizado nas habitaçôes ${ }^{79}$. Também aqui os documentos corroboram o indício, descobrindo-se registos de chaminés apenas pontualmente no século $\mathrm{XV}^{80}$, mas com maior incidência no século seguinte ${ }^{81}$.

${ }^{78}$ Por exemplo, quando o concelho de Silves se queixa ao rei do mau estado dos seus quatro fornos de pão-devido a um anterior tremor de terra-, acrescenta que o almoxarife só reconstruiu três fornos, alguns dos quais "nom eram cubertos como compria” [doc. 561, em Chancelarias Portuguesas, D. Pedro I (1357-1367) (Lisboa, 1984), pp. 245-249]. Já no emprazamento feito pelo Cabido da Sé de Coimbra a Fernão Martins, em 31 de agosto de 1478, de um forno de cozer pão com suas casas sobradadas, encontra-se a especificação de que os enfiteutas deveriam trazer "o dicto forno muramte e cusemte comtynuadamemte e que faça e refaça a dicta cassa do forno e cassas sobradadas de paredes e madeira he telha e pregadura", para que "fyque o dicto forno e casa de forno e casas sobradadas todo aproveytado e melhorado" [doc. 26, publicado por SANTOS, Valério Nuno da Silva, Lavrar documentos para lavrar a terra. Um tombo do Cabido da Sé de Coimbra de finais do Século XV (1472-1482) (Mestrado, Universidade de Coimbra, 2009), pp. 152-154]. Também no Tombo do Mosteiro de Gundar, de 1548-1549, ficou descrito "huu allpendre aa porta contra nasçente que tem huu forno" e "huua casa de forno [...] ao quoall casa de forno he collmaça E teem defronte da porta huu Resio" [doc. 2, publicado por DiAs, João J. Alves, Gentes e espaços (em torno da população portuguesa na primeira metade do século XVI) (Lisboa, 1996), pp. 332, 339].

${ }^{79}$ Beirante, Maria Ângela; Dias, João J. Alves, O património urbano da ordem de Cristo em Évora no início do seculo XVI, in Estudos de Arte e História. Homenagem a Artur Nobre de Gusmão (Lisboa, 1995), p. 69; BeIrante, Maria Ângela, A casa eborense na Idade Média (sécs. XIV-XV), in $O$ ar da cidade, Ensaios de história medieval e moderna (Lisboa, 2008), p. 206; Conde, Manuel Sílvio Alves; VIEIRA, Marina Afonso, A habitação e a arquitectura corrente do Norte Transmontano em finais da Idade Média, in Paisagens Rurais e urbanas. Fontes, Metodologias, Problemáticas, I (Lisboa, 2004), pp. 79, 81, 85 e seg.; GONÇALVES, Iria, A construção corrente na Beira Interior nos finais da Idade Média, in III Congresso Histórico de Guimarães. D. Manuel e a sua época (Guimarães, 2004), III, pp. 116-117.

${ }^{80}$ A palavra portuguesa chaminé deriva do francês cheminée (que por sua vez derivou do latim caminnata), ainda que possa também ter tido influência do vocativo chama. As primeiras ocorrências da palavra surgem nas condições construtivas dos contratos enfitêuticos das casas régias na Rua Formosa do Porto da segunda década do século XV [MACHADO, José Pedro, Dicionário etimológico da língua portuguesa (Lisboa, 1977), II, p. 128].

${ }^{81}$ Por exemplo, nos tombos da Ordem de Cristo do século XVI aparecem descritas várias chaminés, especificando já formas e/ou materiais: "hũua chaminee e hũua freesta junto com ella", "chaminee de dous fogos em cada sobrado seu fogo", "chamjnee de tromba", "chaminee de sebe e bayrro", "chamjnee de Ripa e barro", "chamjnee de barro", "chaminee de pedraria", "chamjnee noua de cal e tijollo", "chaminee de tijollo", "chamjnee de madeira" [Tombos, cit. (n. 19), I, pp. 7, 30; II, pp. 8, 35; III, pp. 74, 230, 231; V, pp. 165, 243; VI, p. 135]. 
Tal permite propor que é neste período de transição que a chaminé se generaliza, quer nas habitaçōes ${ }^{82}$, quer nos fornos. Afinal, em 1509 a Comenda de Mendo Marques tinha na rua de Malforo de Évora uma casa "de dentro honde estaa hũu forno de poya [...] e tem hũua meya chaminee afora a do forno" ${ }^{\text {"3 }}$. Além do mais, se na citada Ordenaçom do foguo de Lisboa, a chaminé parece ser referida por ser um elemento excecional, na segunda metade do século XVI ela já devia ser suficientemente frequente ao ponto de todos os oficiais pedreiros que quisessem ser examinados -segundo o regimento de 1572- terem de "saber muj fazer hũa chimine e dar lhe sey conto cô sua regua e prumo segundo sua largura e altura" 84 .

Mas, é também no período moderno que se descobrem queixas concretas sobre os danos provocados por fumos. Por exemplo: em 1543, é o próprio rei, D. João III, que manda inspecionar um forno na parte de baixo do seu Paço de Santos, tendo-se verificado, com o dono do forno, que a estrutura estava localizada a meio de um olival e distanciada mais de 100 passos da cerca régia, e que "por nã ventar de baixo pera puder leuar ho fumo contra os paços que estom mais acima" não fazia dano, embora tenha sido dito que se nenhum "nojo que ho fumo fazia", "ao menos a vista fazia nojo" 85 . Em 1647, a vereação de Coimbra "mandou parar a obra de hum forno que se fazia por baixo do passo do Conde [a] te se ver se fazia persuizo ao moradores e povo" ${ }^{\prime \prime}$. Em 1668, o capitão António Barriga embargou a obra de uns fornos de cozer pão de João da Silva, em Lisboa, com o fundamento de que aqueles estavam encostados às suas casas arriscando-as ao fogo e ao incêndio, mas que por o encosto não ser verdadeiro, o juiz das propriedades desembargou a obra, obrigando apenas o dono a levantar "a tromba da chaminé mais alto que as janellas do A[utor] em modo, que nem o fumo lhe entre pelas janellas, nem a quentura do fogo lhas aqueça, nem cause prejuizo algum às paredes" ${ }^{7}$. Em 1679, os moradores de Belém queixaram-se ao senado de Lisboa da manufatura da enxárcia pelo "fumo insoportavel” e por ficar na vizinhança de casas “de que tambem resultará prejuizo a saude dos moradores pela má calidade do fumo" 88 .

Assim se compreende a necessidade das autoridades públicas em estabelecer medidas preventivas contra a poluição do ar provocada pelos fumos dos fornos, desde logo pela remoção de determinadas atividades produtivas do interior dos espaços urbanos, tal como se verifica em Coimbra, no século XVI, quando a vereação estabeleceu "Que dentro na cidade nem seus arrabaldes se não cosa cal, telha nem tijelo por ser coisa prejuidical e impiedosa para a cidade por bem dos fumos que

${ }^{82}$ Seguindo também a interpretação de Beirante, Maria Ângela; DiAs, João J. Alves, cit. (n. 79), 1995, p. 69.

${ }^{83}$ Tombos, cit. (n. 19), I, pp. 74-75.

${ }^{84}$ Livro dos regimentos dos officiais mecânicos da mui nobre e sempre leal cidade de Lisboa (1572) (Coimbra, 1926), pp. 106.

${ }^{85}$ ANTT, Corpo Cronológico, Parte I, Maço 73, n. ${ }^{\circ} 100$.

${ }^{86}$ Arquivo Histórico Municipal de Coimbra, Vereaçôes: 1644-1648, fl. 80v.

${ }^{87}$ Acórdão publicado por PEgAs, Manuel Alvares, Commentaria ad ordinationes Regni Portugalliae, Tomus Sextus (Lisboa, 1681), p. 79.

${ }^{88}$ AML-NH, Chancelaria Régia, Livro 60 de Consultas e Decretos de D. Pedro II, fl. 384. 
fazem", com exceção dos oleiros "contanto que todos façam chaminés altas e que defumem bem que não façam dano" $"$.

Mas porque os fornos de pão continuaram a estar localizados perto das habitaçôes $^{90}$, tornou-se, nestes casos, obrigatório construir uma chaminé, de preferência alta. A razão deste preceito assentava nos malefícios provocados pelo fumo, tal como as normas de Lisboa, Coimbra e Leiria abertamente o indicavam: "naão fazendo con o fumo delles nojo aos vizinhos"; "o fumo dos ditos fornos por ser muito preiudicial asim pera a Saude do pouo, como pollo damno $q$ fazem nas familias, $E$ cazas dos uezinhos"; "que não fasa nojo o fumo".

Do ponto de vista jurídico, a imposição da construção das chaminés conseguia até resolver uma indefinição que, sobre o assunto, existia no ius commune, enquanto direito subsidiário do reino ${ }^{91}$. De facto, no direito romano, o dano dos fumos era abordado através de dois testemunhos relatados por Ulpiano (incluindo a indicação dos respetivos meios de defesa $)^{92}$. No primeiro testemunho, sobre um caso concreto, esclarecia-se que a queijaria (taberna caesaria) em questão não podia introduzir fumos nas propriedades superiores, tal como as últimas não poderiam descarregar as águas nas propriedades inferiores. No segundo testemunho, invocando a opinião de outro jurista, limitava-se a repressão daquelas imissões aos fumos leves, isto é, aos fumos suportáveis, como os que saiam das lareiras das habitaçôes. Porém, as interpretações dos juristas medievais sobre estes fragmentos nem sempre coincidiram. Acúrcio considerou que a analogia alvitrada, entre o fumo e a água, não era equivalente porque o primeiro se dispersava naturalmente, sugerindo até que os vizinhos superiores tinham de suportar os fumos das lareiras inferiores bastando-lhes fechar as janelas. Já Bártolo de Sassoferrato -alterando o tipo de estabelecimento mencionado na regra de queijaria para hospedaria (hostaria) ${ }^{93}$ esclareceu que as imissóes permitidas e que deviam ser toleradas pelos vizinhos eram aquelas que derivavam do uso normal, como as da vida familiar (originadas nas lareiras), por oposição às provocadas pelas atividades produtivas, que expeliam muito fumo, devido ao contínuo uso do fogo. Por seu lado, Baldo de Ubaldis, conformando-se com a opinião de outros juristas, certificou o princípio de que

${ }^{89} \$ 898$ do Livro de regimentos e posturas desta mui nobre e sempre leal cidade de Coimbra, (Livro I da Correia), in Arquivo Coimbrão, 5 (1940), pp. 62-63. Ver também o que ficou dito na nota 5 .

${ }^{90}$ A localização destes fornos, durante o período moderno, é francamente atestada em Coimbra, quando, em 1527, a vereação proíbe as pessoas de meterem linhos nos fornos para os manterem quentes "por se acender o fogo de noite nos fornos dentro da cidade o que era grande perigo e por se evitar o grande mal que de semelhante coisa se pode seguir por os ditos fornos de poia estarem dentro na cidade [...] e juntos com a outra povoação" [\$935 do Livro de regimentos, cit. (n. 89), p. 73].

${ }^{91}$ Por todos, ver CRUz, Guilherme Braga da, O direito subsidiário na história do direito português, in Revista Portuguesa de História, 14 (1975), pp. 177-213.

${ }^{92}$ D. 8, 5, 8, 5 e 6 [Corpus Iuris Civilis, cit. (n. 60), p. 121].

${ }^{93}$ No século XVIII, este tipo de estabelecimento foi novamente alterado, pelo jurista Robert Joseph Pothier, referindo-se agora a fornos de cal ou fornos para queimar os resíduos de vinho [GORDLEY, James, Disturbances among neighbours: an introduction, in The development of liability between neighbours (Cambridge, 2014), p. 5]. 
cada um podia apenas fazer o que quisesse na sua propriedade desde que não invadisse a propriedade alheia. Os juristas do início do período moderno também mantiveram a mesma divergência compreensiva do texto romano, não conseguindo chegar uma regra clara, ainda que muitas vezes seguissem a interpretação de Bártolo. Todavia, a dificuldade encontrava-se, precisamente, em demarcar os usos normais dos anormais e quantificar o que era considerado como muito fumo ${ }^{94}$.

Assim, com o confinamento de algumas atividades produtivas fora das áreas urbanas e sobretudo através da obrigatoriedade da construção de chaminés para as atividades que se mantinham perto das habitaçôes, conseguia-se chegar a uma espécie de compromisso sobre a legalidade ou ilegalidade da imissão dos fumos dos fornos. É que a principal função da chaminé era impulsionar o fumo para cima dos telhados e dissipá-lo na atmosfera, ventilando ainda a casa do forno. Em simultâneo, o ar circundante na vizinhança tornava-se menos poluído e mais suportável, e o muito fumo passava a pouco fumo. Talvez por isso, quando o concelho de Lisboa modifica a norma dos fornos e sugere a construção de chaminés ou outros resguardos para evitar os danos fumos, afirme expressamente "Segumdo ho direito Em tal caso manda".

\section{ENCERRAMENTO}

Em suma, os dados recolhidos nas fontes documentais testemunham, claramente, que os fornos em geral e os fornos de pão em particular (por se localizarem perto das habitaçôes, já que era dali que saía o principal alimento das populações), foram, desde cedo, alvo de regulação específica por parte das autoridades locais portuguesas. Tais normas jurídicas procuravam proteger as propriedades vizinhas contra os danos provocados por estas estruturas. Dos afastamentos espaciais, provavelmente aplicados apenas nas maiores povoaçôes, seguiu-se a obrigatoriedade, utilizada em várias povoações, de lhes serem sobrepostas chaminés.

Mas este episódio, sobre o ordenamento jurídico para a construção de fornos de pão, revela-se ainda essencial para atestar uma mudança socio-ambiental que ocorreu na transição do medievo para a modernidade: a poluição do ar passou a fazer parte das questões de salubridade pública que concelhos tinham de dar resposta, por lhes competir zelar pelo bem comum, tal como, até então, faziam relativamente à higiene ambiental, pela qual se procurava evitar a corrupção orgânica do ar, das águas, dos alimentos e dos lugares.

Por certo, a poluição do ar pelo fumo dos fornos em Portugal, durante o período moderno, mesmo na maior cidade do reino, não seria tão gravosa e nem teria efeitos concretos na saúde das pessoas como aquela que se começava a sentir em algumas cidades europeias. Londres é a esse respeito paradigmática, também

${ }^{94}$ Gordley, James, cit. (n. 93), pp. 2-5; O Mesmo, Ius Quaerens Intellectum: The Method of the Medieval Civilians, in The Creation of the Ius Commune, From Casus to Regula (Edinburgh, 2010), pp. 82-85; Amunátegui Perelló, Carlos Felipe, Hacia un concepto de inmisiones en el derecho chileno, in Revista Chilena de Derecho, 40/1 (2013), pp. 46-58. Ver também Justo, António Santos, As relaçôes de vizinhança e a "Cautio Damni Infecti" (Direito Romano. Época Clássica), in Dereito, 2/2 (1993), pp. 80-81. 
muito por culpa de se ter passado a utilizar o carvão, em vez da lenha, quer a nível produtivo, quer a nível doméstico, desde tempos medievais ${ }^{95}$. Tal alteração de combustível não ocorreu, de facto, em Portugal ${ }^{96}$. Não obstante, a perceção sobre a poluição do ar e as medidas estabelecidas pelas autoridades para a precaver revelaram-se similares às utilizadas por aquelas outras cidades, permitindo constatar que, nesta matéria, o ordenamento jurídico português estava perfeitamente alinhado com as soluções mais modernas entretanto adotadas noutros países.

\section{BiBLIOGRAFIA}

Albuquerque, Ruy de; Albuquerque, Martim de, História do direito português, 11401415 (Sintra, 2005).

Amunátegui Perelló, Carlos Felipe, Hacia un concepto de inmisiones en el derecho chileno, in Revista Chilena de Derecho, 40/1 (2013), pp. 46-86.

Ashtor, Eliyahu, Makāyil - 1. In the Arabic, Persian and Turkish Lands, in The Encyclopaedia of Islam, New Edition, 12 vols. (Leiden, 1986-2004), VI, pp. 117-121.

BARBIER, Droit Musulman: des droits et obligations entre propriétaires d'héritages voisins, in Revue Algérienne et Tunisienne de Législation \& de Jurisprudence, 16 (1900), pp. 10-3, 17-23, 42-56, 93-104, 113-28, 129-44; 17 (1901), pp. 65-84, 89-108.

Barros, Henrique Gama, História da administração pública em Portugal nos séculos XII a XV, 4 vols. (Lisboa, 1885-1922).

BeIRANTE, Maria Ângela, Santarém Medieval (Lisboa 1980).

- A casa eborense na Idade Média (sécs. XIV-XV), in $O$ ar da cidade, Ensaios de história medieval e moderna (Lisboa, 2008), pp. 201-208

- Saúde pública em Évora durante a baixa Idade Média, in $O$ ar da cidade, Ensaios de história medieval e moderna (Lisboa, 2008), pp. 223-233.

Beirante, Maria Ângela; Dias, João J. Alves, O património urbano da ordem de Cristo em Évora no início do seculo XVI, in Estudos de Arte e História. Homenagem a Artur Nobre de Gusmão (Lisboa, 1995), pp. 61-79.

BRANDĀo, João, Grandeza e abastança de Lisboa em 1552 (Lisboa, 1990).

BrandÃo, Zeferino, Monumentos e lendas de Santarém (Lisboa, 1883).

BRIMBLECOMBE, Peter, The big smoke. A history of air pollution in London since medieval times (Oxon, 2011).

CaEtano, Marcello, História do direito português: Fontes - Direito público (1140-1495) (Lisboa, 1985).

Carvalho, Afonso, Da toponimia de Évora, 2 vols. (Lisboa, 2004-2007).

Carvalho, J.M. Teixeira, A cerâmica de Coimbra (Séculos XVI e XVII), in Revista da Universidade de Coimbra, 6 (1917), pp. 183-241, 422-468.

\footnotetext{
${ }^{95}$ Brimblecombe, Peter, cit. (n. 77), pp. 5-89; CAVert, William M., The Smoke of London: Energy and Environment in the Early Modern (Cambridge, 2016), pp. 61-80.

${ }^{96} \mathrm{Em}$ meados do século XVI, era ainda a lenha que alimentava quase todos os fornos lisboetas, ao ponto de, em 1562, se ter determinado, por alvará régio, o afastamento dos fornos de vidro sete léguas ao redor da cidade, não por causa do fumo, mas por gastarem muita lenha, pois ardiam continuamente "mingoando e encarecendo [a lenha] cada vez mais em muito prejuizo do povo" [Documentos, cit. (n. 47), VIII, p. 17].
} 
Carvalho, Maria José Pereira, Documentação Medieval do Mosteiro de Santa Maria de Alcobaça (sécs. XIII-XVI). Edição e estudo linguístico (Doutoramento, Universidade de Coimbra, 2006).

Cavert, William M., The Smoke of London: Energy and Environment in the Early Modern (Cambridge, 2016).

Chassan, Joseph Pierre, Essai sur la symbolique du droit, précédé d'une introduction sur la poésie du droit primitif (Paris, 1847).

Conde, Manuel Sílvio Alves; Vieira, Marina Afonso, A habitação e a arquitectura corrente do Norte Transmontano em finais da Idade Média, in Paisagens Rurais e urbanas. Fontes, Metodologias, Problemáticas (Lisboa, 2004), I, pp. 65-122.

Costa, Mário Júlio Almeida, História do direito português (Coimbra, 2009).

Cruz, Guilherme Braga da, $O$ direito subsidiário na história do direito português, in Revista Portuguesa de História, 14 (1975), pp. 177-213.

Cunha, Maria Cristina; Pimenta, Maria Cristina, A comenda de Albufeira da Ordem de Avis nos inicios do século XV: breve abordagem, in Actas das I Jornadas do Algarve e da Andaluzia (Loulé, 1987), pp. 305-347.

DiAs, João J. Alves, Gentes e espaços (em torno da população portuguesa na primeira metade do século XVI) (Lisboa, 1996).

DOMINGUES, José, O elemento castelhano-leonês na formação do direito medieval português, in Cuadernos de Historia del Derecho, 21 (2014), pp. 213-227.

Domingues, José; Pinto, Pedro, Os foros extensos na Idade Média em Portugal, in REHJ., 37 (2015), pp. 153-174.

Dutra, Francis A., Os fornos da Ordem de Santiago e seus Comendadores 1550-1777, in Ordens Militares. Guerra, religiāo, poder e cultura: Actas do III Encontro sobre Ordens Militares (Lisboa, 1999), pp. 179-183.

Gómez Rojo, María Encarnación, Historia juridica del incendio en la Edad Antigua y en el ordenamiento medieval castellano: Implicaciones urbanisticas y medioambientales, in REHJ., 33 (2011), pp. 321-373.

-Precedents de la legislació mediambiental. Repressió penal i prevenció urbanistica dels danys produïts pel foc en algunes fonts del dret aplicades a Cataluya durant l'Edat Mitjana, in Revista de Dret Històric Català, 11 (2011-2012), pp. 97-145.

GonçALVES, Iria, O património do Mosteiro de Alcobaça nos séculos XIV e XV (Lisboa, 1989).

- A construção corrente na Beira Interior nos finais da Idade Média, in III Congresso Histórico de Guimarães. D. Manuel e a sua época, 4 vols. (Guimarães, 2004), III, pp. 101-123.

- A propósito do pão da cidade na Baixa Idade Média, in Turres Veteras IX. História da Alimentação (Torres Vedras, 2007), pp. 49-72.

GonZÁlEZ ARCE, José Damián, Cuadernos de ordenanzas y otros documentos sevillanos del reinado de Alfonso X, in Historia, Instituciones, Documentos, 16 (1989), pp. 103-132.

Gordley, James, Disturbances among neighbours: an introduction, in The development of liability between neighbours (Cambridge, 2014), pp. 1-28.

-Ius Quaerens Intellectum: The Method of the Medieval Civilians, in The Creation of the Ius Commune, From Casus to Regula (Edinburgh, 2010), pp. 77-101.

Hespanha, António Manuel, História das instituiçôes, Épocas medieval e moderna (Coimbra, 1982).

-Cultura jurídica europeia, síntese de um milénio (Coimbra, 2012). 
Higounet-Nadal, Arlette, Périguex aux XIVe et XVe siècles. Étude de démographie historique, 2 vols. (Université de Lille III, 1979).

Justo, António Santos, As relaçôes de vizinhança e a "Cautio Damni Infecti" (Direito romano. Época clássica), in Dereito, 2-2 (1993), pp. 75-111.

Lopes, Fábio Morgado, Posturas de Leiria (séc. XVI-XIX): Contributo para o estudo da administração municipal em Portugal (Mestrado, Universidade de Coimbra, 2003).

LOPES, Luís Seabra, Sistemas legais de medidas de peso e capacidade, do Condado Portucalense ao século XVI, in Portvgalia, Nova Série, 24 (2003), pp. 113-164.

Machado, José Pedro, Dicionário etimológico da língua portuguesa, 5 vols. (Lisboa, 1977).

Marques, A.H. de Oliveira, Introdução à história da agricultura em Portugal. A questão cerealifera durante a Idade Média (Lisboa, 1978).

-Pesos e Medidas, in Dicionário de história de Portugal, 6 vols. (Lisboa, 1984), V, pp. $62-72$.

Marques, A.H. de Oliveira; Gonçalves, Iria; Andrade, Amélia Aguiar (org.), Atlas de Cidades Medievais Portuguesas (Séculos XII-XV) (Lisboa, 1990).

Marques, José, A administração municipal de Mós de Moncorvo em 1439, in Brigantia, Revista de Cultura, 5-2/3/4 (1985), pp. 515-560.

- A Ordem de Santiago e o concelho de Setúbal, em 1341, in As Ordens Militares em Portugal e no Sul da Europa (Lisboa, 1992), pp. 285-305.

-D. Manuel I e os fornos comunitários transmontanos, in Amar, sentir e viver a história: Estudos de homenagem a Joaquim Veríssimo Serrão (Lisboa, 1995), pp. 647-659.

Mata, Joel Silva Ferreira, A comunidade feminina da Ordem de Santiago: A comenda de Santos em finais do século XV e no século XVI. Um estudo religioso, económico e social (Porto, 2007).

Mattoso, José, A consolidação da monarquia e a unidade política, in História de Portugal, 8 vols. (Lisboa, 1993), II, pp. 269-296.

Michelet, Jules, Origines $d u$ droit français, cherchées dans les symboles et formules $d u$ droit universel (Paris, 1837).

MonCADA, Luís Cabral, $A$ "traditio" e a transferência da propriedade imobiliária no direito português (séculos XII-XV), in Boletim da Faculdade de Direito da Universidade de Coimbra, 6 (1920-1921), pp. 472-496.

Moura, Álvaro de Mendonça Gomes de, Alguns séculos de administração sanitária, Subsidios para a sua história na cidade do Pôrto e no seu termo (Lisboa, 1945).

MuHAMAD, Mohd Dani, Rules for compact urbanism, Ibn al-Rami's $14^{\text {th }}$ cemtury treatise (2017).

Nogueira, José Duarte, A organização municipal da Extremadura Leonesa nos sécs. XII e XIII, in Boletim da Faculdade de Direito, 58/2 (1982), pp. 373-431.

Oliveira, Nicolau de Oliveira, Livro das Grandezas de Lisboa (Lisboa, 1620).

Padilla Mellado, Lorenzo, Autos y pleito de derribo de hornos que cada vecino tenía fecho en su casa en alquerías de la vega de Granada y Valle de Lecrin, in Revista del Centro de Estudios Históricos de Granada y su Reino, 21 (2008), pp. 261-286; 22 (2010), pp. 211-242.

Pegas, Manuel Alvares, Commentaria ad ordinationes Regni Portugalliae, Tomus Sextus (Lisboa, 1681).

Pereira, Maria Helena da Rocha, Obras médicas de Pedro Hispano (Coimbra, 1973). 
Piedrafita Pérez, Elena, Infraestructura económica de los concejos de las Cinco Villas: regadios, molinos y hornos (siglos XII-XIV), in Aragón en la Edad Media, 12 (1995), pp. 29-60.

Pimenta, Belisário, As cartas do Infante D. Pedro à Câmara de Coimbra (1429-1448), in Arquivo de História e Bibliografia, 1923-1926 (Lisboa, 1976), I, pp. 127-166.

Pimenta, Maria Cristina, As Ordens de Avis e de Santiago na Baixa Idade Média: O governo de D. Jorge (Porto, 2001).

Pimentel, Luís Serrão, Arte Prática de Navegar e Regimento de Pilotos repartido em duas partes (Lisboa, 1681).

PINTO, Sandra M.G., Em torno do foral medieval da almotaçaria de Lisboa, in Fragmenta Historica: História, Paleografia e Diplomática, 4 (2016), pp. 47-110.

-O licenciamento dos estabelecimentos insalubres, incómodos ou perigosos no século XIXe as plantas dos processos do distrito de Coimbra, in Boletim do Arquivo da Universidade de Coimbra, 31/1 (2018), pp. 125-162.

ReI, António, Pesos e medidas de origem islâmica em Portugal, Notas para o seu estudo (Évora, 1998).

ReIs, António Matos, Origem dos Municípios Portugueses (Lisboa, 2002).

Rodrigues, Maria Teresa Campos, Aspectos da administração municipal de Lisboa no século XV (Lisboa, 1968).

Roque, Mário da Costa, As pestes medievais europeias e o "Regimento proueytoso contra ha pestenença", Lisboa, Valentim Fernandes (1495-1496). Tentativa de interpretação à luz dos conhecimentos pestológicos actuais (Paris, 1979).

SÁnchez Domingo, Rafael, Traditio: Rito, símbolo y título en la transmissión de la tierra, in Glossae, European Journal of Legal History, 12 (2015), pp. 757-781.

SAntos, Valério Nuno da Silva, Lavrar documentos para lavrar a terra. Um tombo do Cabido da Sé de Coimbra de finais do Século XV (1472-1482) (Mestrado, Universidade de Coimbra, 2009).

Serra, Pedro Cunha, O "arrátel folforinho", in Revista Portuguesa de História, 13 (1971), pp. 139-144.

Silva, Nuno Espinosa Gomes, História do direito português, Fontes de direito (Lisboa, 2011).

Slater, Terry R.; Pinto, Sandra M.G., Building regulations and urban form. An introduction, in Building Regulations and Urban Form, 1200-1900 (Oxon, 2018), pp. 1-21.

STumpF, Gerd, Litra, in Brill's New Pauly: Encyclopedia of the Ancient World: Antiquity, Vol. 7. (Leiden, 2005), p. 727.

Tavares, Maria Alice, Costumes e foros de Riba-Côa: Normativa e sociedade (Doutoramento, Universidade de Lisboa, 2013).

TAVAres, Maria José Ferro, A politica municipal de saúde pública (séculos XIV-XV), in Revista de História Económica e Social, 19 (1987), pp. 17-32. 